\title{
The physiological effect of heavy metals and volatile fatty acids on Methanococcus maripaludis S2
}

\author{
Annalisa Abdel Azim 1,2,3, Simon K.-M. R. Rittmann ${ }^{2 *} \mathbb{D}$, Debora Fino ${ }^{3}$ and Günther Bochmann ${ }^{1}$
}

\begin{abstract}
Background: Methanogenic archaea are of importance to the global C-cycle and to biological methane $\left(\mathrm{CH}_{4}\right)$ production through anaerobic digestion and pure culture. Here, the individual and combined effects of copper (Cu), zinc $(\mathrm{Zn})$, acetate, and propionate on the metabolism of the autotrophic, hydrogenotrophic methanogen Methanococcus maripaludis S2 were investigated. Cu, Zn, acetate, and propionate may interfere directly and indirectly with the acetyl$\mathrm{CoA}$ synthesis and biological $\mathrm{CH}_{4}$ production. Thus, these compounds can compromise or improve the performance of M. maripaludis, an organism which can be applied as biocatalyst in the carbon dioxide $\left(\mathrm{CO}_{2}\right)$-based biological $\mathrm{CH}_{4}$ production $\left(\mathrm{CO}_{2}\right.$-BMP) process or of methanogenic organisms applied in anaerobic digestion.

Results: Here, we show that Cu concentration of $1.9 \mu \mathrm{mol} \mathrm{L} \mathrm{L}^{-1}$ reduced growth of M. maripaludis, whereas 4.4 and $6.3 \mu \mathrm{mol} \mathrm{L} \mathrm{L}^{-1}$ of $\mathrm{Cu}$ even further retarded biomass production. However, $1.0 \mathrm{mmol} \mathrm{\textrm {L } ^ { - 1 }}$ of $\mathrm{Zn}$ enhanced growth, but at $\mathrm{Zn}$ concentrations $>2.4 \mathrm{mmol} \mathrm{L}^{-1}$ no growth could be observed. When both, $\mathrm{Cu}$ and $\mathrm{Zn}$, were supplemented to the medium, growth and $\mathrm{CH}_{4}$ production could even be observed at the highest tested concentration of $\mathrm{Cu}$ $\left(6.3 \mu \mathrm{mol} \mathrm{\textrm {L } ^ { - 1 }}\right)$. Hence, it seems that the addition of $1 \mathrm{mmol} \mathrm{L}^{-1}$ of $\mathrm{Zn}$ enhanced the ability of $\mathrm{M}$. maripaludis to counteract the toxic effect of $\mathrm{Cu}$. The physiological effect to rising concentrations of acetate $\left(12.2,60.9,121.9 \mathrm{mmol} \mathrm{L}^{-1}\right)$ and/or propionate $\left(10.3,52.0,104.1 \mathrm{mmol} \mathrm{L}^{-1}\right)$ was also investigated. When instead of acetate $10.3 \mathrm{mmol} \mathrm{L}^{-1}$ propionate was provided in the growth medium, M. maripaludis could grow without reduction of the specific growth rate $(\mu)$ or the specific $\mathrm{CH}_{4}$ productivity $\left(\mathrm{qCH}_{4}\right)$. A combination of inorganic and/or organic compounds resulted in an increase of $\mu$ and $\mathrm{qCH}_{4}$ for $\mathrm{Zn} / \mathrm{Cu}$ and $\mathrm{Zn} /$ acetate beyond the values that were observed if only the individual concentrations of $\mathrm{Zn}, \mathrm{Cu}$, acetate were used.

Conclusions: Our study sheds light on the physiological effect of VFAs and heavy metals on M. maripaludis. Differently from $\mu$ and $\mathrm{qCH}_{4}, \mathrm{MER}$ was not influenced by the presence of these compounds. This indicated that each of these compounds directly interacted with the C-fixation machinery of M. maripaludis. Until now, the uptake of VFAs other than acetate was not considered to enhance growth and $\mathrm{CH}_{4}$ production of methanogens. The finding of propionate uptake by M. maripaludis is important for the interpretation of VFA cycling in anaerobic microenvironments. Due to the importance of methanogens in natural and artificial anaerobic environments, our results help to enhance the understanding the physiological and biotechnological importance with respect to anaerobic digestion, anaerobic wastewater treatment, and $\mathrm{CO}_{2}$-BMP. Finally, we propose a possible mechanism for acetate uptake into M. maripaludis supported by in silico analyses.
\end{abstract}

Keywords: Archaea, Methanogen, Metabolism, Closed batch, Copper, Zinc, Acetate, Propionate

\footnotetext{
*Correspondence: simon.rittmann@univie.ac.at

2 Archaea Physiology \& Biotechnology Group, Archaea Biology and Ecogenomics Division, Department of Ecogenomics and Systems

Biology, Universität Wien, Althanstraße 14, 1090 Vienna, Austria

Full list of author information is available at the end of the article
}

(c) The Author(s) 2018. This article is distributed under the terms of the Creative Commons Attribution 4.0 International License (http://creativecommons.org/licenses/by/4.0/), which permits unrestricted use, distribution, and reproduction in any medium, provided you give appropriate credit to the original author(s) and the source, provide a link to the Creative Commons license, and indicate if changes were made. The Creative Commons Public Domain Dedication waiver (http://creativecommons.org/ publicdomain/zero/1.0/) applies to the data made available in this article, unless otherwise stated. 


\section{Background}

Methane $\left(\mathrm{CH}_{4}\right)$ is one of the most important and most used energy gases worldwide [1]. $\mathrm{CH}_{4}$ is produced by strictly anaerobic methanogenic archaea (methanogens), which contribute to the global carbon cycle with approximately $1 \mathrm{Gt}$ of $\mathrm{CH}_{4}$ produced per year [2]. The carbon and energy metabolism of methanogens is streamlined for the conversion of a restricted number of $\mathrm{C} 1$ and $\mathrm{C} 2$ substrates, i.e. carbon dioxide $\left(\mathrm{CO}_{2}\right)$ and molecular hydrogen $\left(\mathrm{H}_{2}\right)$, formate, acetate, methanol, methylamines, and methoxylated compounds. Among the methanogens, the physiology and metabolism of Methanococcus maripaludis S2 harbours intriguing characteristics, including a high specific growth rate $(\mu)$, mild growth temperature $\left(35-39^{\circ} \mathrm{C}\right)$, genetically manipulability due to the presence of selectable markers [3], and an effective method for transformation [4]. These features make $M$. maripaludis an excellent laboratory microorganism for physiological and biotechnological studies [5]. Being an autotrophic, hydrogenotrophic methanogen, $M$. maripaludis could be applied for $\mathrm{CO}_{2}$ mitigation through the $\mathrm{CO}_{2}$-based biological $\mathrm{CH}_{4}$ production ( $\mathrm{CO}_{2}$-BMP) process [6-8]. Furthermore, $M$. maripaludis was suggested to be applicable for wastewater treatment, amino acid production, and value-added product synthesis [9]. Despite the enormous biotechnological potential of methanogenic archaea in general $[6,8,10-13]$ and of M. maripaludis in particular $[9,14,15]$, the physiological knowledge with respect to the putative toxicology towards heavy metals such as cadmium, chromium, copper $(\mathrm{Cu})$, mercury, uranium, zinc $(\mathrm{Zn})$, and volatile fatty acids (VFAs), e.g. acetate and propionate, is still limited.

The inhibitory effects of heavy metals and VFAs on biological methanogenesis have been investigated in mixed and pure cultures [16-19]. Many surveys on biogas production from anaerobic digestion examined the mutual influence of heavy metals and VFA degradation [20-23]. VFAs are known to possess antimicrobial properties that are responsible for alterations in membrane functions like membrane fusion induction, inhibition of amino acids transport, and uncoupling of chemiosmotic phosphorylation [24]. These alterations are due to the interference of organic acids with the establishment and maintenance of a functional $\mathrm{pH}$ gradient across the membrane, that can lead to inhibition of methanogenesis [25]. The impact of various concentrations of VFAs on methanogenic communities' variation during anaerobic digestion was also largely investigated [25-27]. However, VFAs do not seem to modify the composition of the methanogenic population in anaerobic digesters [27].

With respect to pure cultures of methanogens, a tolerance towards VFAs $>60 \mathrm{mg} \mathrm{L}^{-1}$ was observed in Methanosarcina barkeri, Methanothermobacter marburgensis, and Methanobacterium formicicum [18]. Besides the toxic effects that these compounds may cause, acetate can be a source of carbon in the metabolism of autotrophic methanogens and enhance their biomass production, depending on the microbial species. In M. marburgensis, acetate can be assimilated and integrated in amino acids although it is not required for growth [28]. In Methanothermococcus okinawensis, acetate does not promote growth [29]. In M. maripaludis, acetate serves as a precursor for acetyl-CoA, which is synthetized via an AMP-forming acetate-CoA synthetase $[30,31]$ and is subsequently assimilated into cell carbon; however, aceticlastic methanogenesis does not occur [32, 33]. While methanogenesis and carbon fixation into biomass compete for $\mathrm{CO}_{2}$ during growth of $M$. maripaludis on $\mathrm{H}_{2} / \mathrm{CO}_{2}$, changes in acetate concentrations may alter the cellular carbon assimilation to the advantage of $\mathrm{CH}_{4}$ production. Moreover, it was shown that VFAs own an amplifying effect on the inhibitory activity of transition metals in pure cultures of various microorganisms such as Escherichia coli, Bacillus subtilis, and Pseudomonas aeruginosa [34]. Thus, VFAs act as transporters for transition metals through the permeable cytoplasmic membrane, inducing an increased entry of metals into the cell.

$\mathrm{Zn}$ and $\mathrm{Cu}$ are involved in the metabolism of many methanogens with a defined role in cell growth and methanogenesis [17]. There, $\mathrm{Zn}$ could be growth stimulating [17]. Indeed, RNA polymerase and other biosynthetic enzymes need $\mathrm{Zn}$ ions. $\mathrm{Zn}$ is the metal coordinator of a cysteine at the N-terminal of the subunit B of the heterodisulfide reductase (Hdr) complex in M. marburgensis [35]. Hdr provides one pair of high potential electrons to reduce the heterodisulfide of coenzyme $\mathrm{B}$ and coenzyme $\mathrm{M}$ (CoB-S-S-CoM) and one pair of low potential electrons, which are required for producing a reduced ferredoxin which is in turn fundamental for $\mathrm{CO}_{2}$ reduction in the first step of $\mathrm{CO}_{2}$ fixation in the methyl branch of the Wood-Ljungdahl pathway. Zn was also found in the active site of the methyl-tetrahydromethanopterin $\left(\mathrm{H}_{4} \mathrm{MPT}\right) \mathrm{CoM}$ methyltransferase (Mtr) enzyme of Methanosarcina barkeri [36-39]. Moreover, $\mathrm{Cu}$ and $\mathrm{Zn}$ possibly inhibit the synthesis of acetyl-CoA via carbon monoxide dehydrogenase/acetyl-CoA synthase $(\mathrm{CODH} / \mathrm{ACS})$ by replacing the proximal nickel $(\mathrm{Ni})$ site of the bimetallic $\mathrm{Ni}-\mathrm{Ni}$ centre in the A cluster of the ACS enzyme [40-42]. The susceptibility of the $\mathrm{Ni}-\mathrm{Ni}$ centre to $\mathrm{Cu}$ or $\mathrm{Zn}$ substitution depends on the conformational state of the $\alpha$ subunit of the ACS and increases with this order $\mathrm{Cu}>\mathrm{Zn}$ [41].

The novelties of this work are the assessment of individual and combined effects of two heavy metals, $\mathrm{Cu}$ and $\mathrm{Zn}$, and two VFAs, acetate and propionate, on growth and $\mathrm{CH}_{4}$ productivity of $M$. maripaludis $\mathrm{S} 2$ grown in 
closed batch cultivation mode on $\mathrm{H}_{2} / \mathrm{CO}_{2}$ (Fig. 1). $M$. maripaludis was tested at concentrations of these compounds higher then physiologically required. Moreover, to determine the role of acetate, we examined the effect of its deprivation. Although $\mathrm{Cu}, \mathrm{Zn}$, and acetate are known to be involved in pathways leading to acetyl-CoA formation and methanogenesis, the role of propionate had not yet been investigated. Hence, we investigated whether propionate could be used to stimulate growth and $\mathrm{CH}_{4}$ production of $M$. maripaludis. Moreover, the effects of acetate or/and propionate, in combination or without $\mathrm{Cu}$ or $\mathrm{Zn}$, on the growth and $\mathrm{CH}_{4}$ productivity of $M$. maripaludis were examined in the light of the consolidated knowledge that was available in literature with respect to the role of acetate, propionate, $\mathrm{Cu}$, and $\mathrm{Zn}$ during methanogenesis. The findings of our study have implications for improving biogas production from anaerobic digestion as well as for $\mathrm{CH}_{4}$ production during $\mathrm{CO}_{2}$-BMP and shed light on the ecophysiological importance of methanogens in VFA cycling in anaerobic environments.

\section{Results and discussion}

Methanococcus maripaludis S2 was grown in defined m141 medium. The absence of vitamins, $\mathrm{Cu}$, and $\mathrm{Zn}$ compounds did not affect growth and productivity (Additional file 1). Therefore, the m141 medium was subsequently used as the standard medium for all closed batch experiments.

\section{Growth of $M$. maripaludis is improved by addition of $\mathrm{Zn}$}

$\mathrm{Zn}$ and $\mathrm{Cu}$, as well as the other heavy metals, originate from natural and anthropogenic sources, and are found in Earth's crust. These compounds are spread in the environment through, e.g. volcanic activity, forest fires, atmospheric deposition, and human activities [43]. Domestic effluents and agricultural and industrial activities, such as mining, refining, combusting, lead to environmental contamination by metals [44]. $\mathrm{Zn}$ and $\mathrm{Cu}$ are considered trace elements together with other metals since their functions in many physiological and biochemical reactions are vital for the functioning of the metabolism. The biological availability depends on chemical, physical, and biological factors [45]. The effect of $\mathrm{Zn}$ and $\mathrm{Cu}$ toxicity on methanogenesis was widely studied in the context of anaerobic digestion of sewage sludge, but only few studies did yet cover the effect of those heavy metals on pure culture of microorganisms.

The individual and combined effects of increasing $\mathrm{Zn}$ and $\mathrm{Cu}$ concentrations on the growth of $M$. maripaludis were determined by monitoring OD changes (Fig. 2). The results indicated that growth of $M$. maripaludis was completely inhibited at 2.4 and $3.5 \mathrm{mmol} \mathrm{L}^{-1}$ of $\mathrm{Zn}$ (Fig. 2a). An addition of $1.0 \mathrm{mmol} \mathrm{L}^{-1}$ of $\mathrm{Zn}$ did only result in a markedly longer lag phase compared to the positive control (medium m141). Conversely, the responsiveness of this microorganism to $\mathrm{Cu}$ toxicity seems to be higher since the $\mathrm{Cu}$ concentrations under which $M$. maripaludis

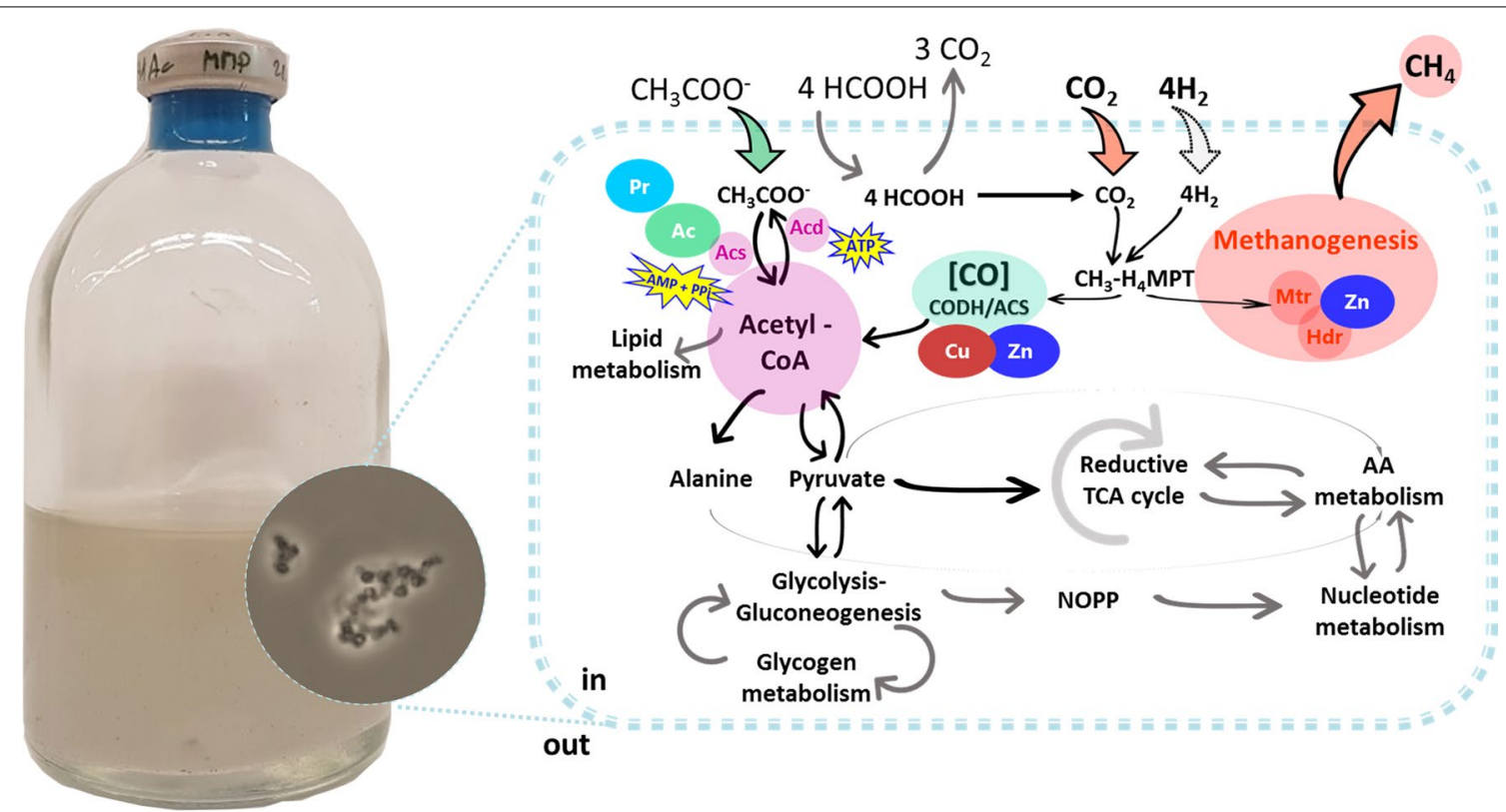

Fig. 1 Schematic representation of the interactions in the metabolisms of M. maripaludis in closed batch cultures and the compounds tested in the present study. Hdr heterodisulfide reductase, Mtr methyl transferase, Acs acetyl-CoA (AMP-forming), Acd acetyl-CoA synthetase (ADP-forming), ATP adenosine triphosphate formation, AMP + PPi adenosine monophosphate and pyrophosphate from ATP hydrolysis, AA amino acid, NOPP non-oxidative pentose phosphate, TCA tricarboxylic acid, $\mathrm{CH}_{3}-\mathrm{HMPT}$ methyl-tetrahydromethanopterin. The present image was inspired by [9, 73] 

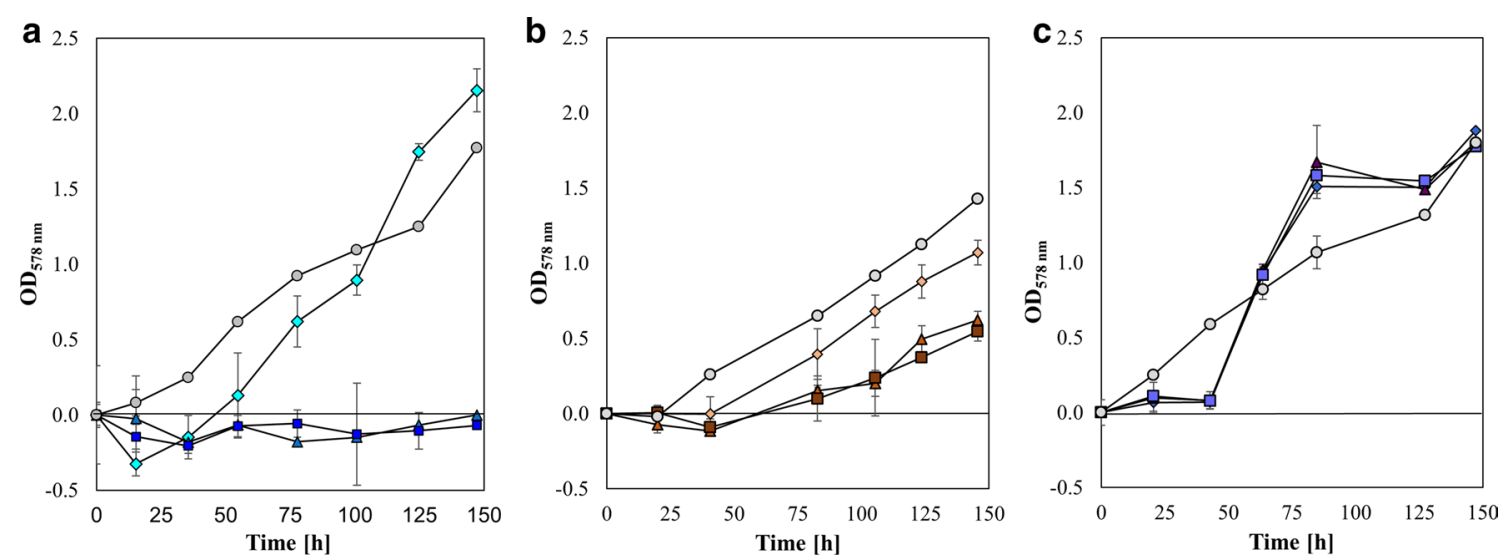

Fig. $2 \mathrm{OD}_{578 \mathrm{~nm}}$ curves of M. maripaludis $50 \mathrm{~mL}$ culture at $37^{\circ} \mathrm{C}, 140 \mathrm{rpm}, 2.9$ bar with $\mathrm{Zn}, \mathrm{Cu}$, and $\mathrm{Zn}$ and $\mathrm{Cu}(n=4)$. M. maripaludis was grown on

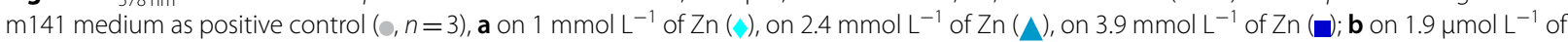

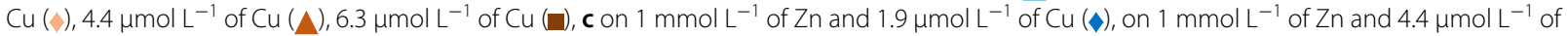
$\mathrm{Cu}(\mathbf{\Lambda})$, on $1 \mathrm{mmol} \mathrm{L}^{-1}$ of $\mathrm{Zn}$ and $6.3 \mu \mathrm{mol} \mathrm{L} \mathrm{L}^{-1}$ of $\mathrm{Cu}(\square)$

growth was still observable were of two order magnitudes lower than for $\mathrm{Zn}$. Despite the recommended concentration of $\mathrm{Cu}$ of $0.6 \mu \mathrm{mol} \mathrm{L}{ }^{-1}$ in methanogenium medium (DSMZ medium 141), M. maripaludis could still grow at $1.9,4.4$, and $6.3 \mu \mathrm{mol} \mathrm{L}{ }^{-1}$, though the maximum OD values were $1.07 \pm 0.08,0.62 \pm 0.06,0.54 \pm 0.06$, respectively, compared to $1.43 \pm 0.001$ in the positive control (medium m141) (Fig. 2b). Therefore, a direct correlation between increasing $\mathrm{Cu}$ concentration in the growth medium and a lower final biomass concentration of $M$. maripaludis seems to be very likely. These results are in agreement with earlier reports on Moorella thermoacetica, where a concentration of $\mathrm{Cu}\left(\mathrm{CuCl}_{2}\right)$ higher than $1 \mu \mathrm{mol} \mathrm{L}{ }^{-1}$ in the medium is deleterious, and $10 \mu \mathrm{mol} \mathrm{L}^{-1}$ of $\mathrm{Cu}$ caused a $50 \%$ reduction of the $\mathrm{CODH}$ and ACS activity due to an alteration of the $\mathrm{Cu}$ content in the enzymes active site [46]. However, there are also species which showed a higher tolerance to $\mathrm{Cu}$. The $\mathrm{Cu}$ concentrations needed for reducing methanogenesis by $50 \%$ in $M$. formicicum, Methanobacterium hungatei, $M$. barkeri, and $M$. marburgensis were $26,30.5,17$, and $35.7 \mu \mathrm{mol} \mathrm{L}^{-1}$, respectively [18]. The elevated resistance of Methanothermobacter thermoautotrophicum KHT-2 to $\mathrm{Cu}$ was shown by a complete growth inhibition at $1 \mathrm{mmol} \mathrm{L}^{-1}$ of $\mathrm{Cu}$ [47]. One main issue in measuring $\mathrm{OD}$ in presence of elevated concentrations of $\mathrm{Cu}$ is related to the formation of agglomerates in the medium due to $\mathrm{Cu}$-sulphide precipitation. The sulphide $\left(\mathrm{Na}_{2} \mathrm{~S} \cdot 9 \mathrm{H}_{2} \mathrm{O}\right)$ concentration in the medium is $0.5 \mathrm{~g} \mathrm{~L}^{-1}$. However, to account for this effect the absorbance of the negative control (sample containing medium only) was subtracted from the replicates. The formation of $\mathrm{Cu}$-sulphide precipitates fluctuated over time. This effect could mitigate the toxicity of $\mathrm{Cu}$ as in the $\mathrm{Cu}$-sulphide form the compound is not available for the microorganisms [48, 49]. By combining $\mathrm{Zn}$ and $\mathrm{Cu}$ at each selected concentration (Fig. 2c), the lag phase lasted $40 \mathrm{~h}$. The three growth curves overlap almost perfectly. Moreover, the maximum OD values range between $1.88 \pm 0.09$ and $1.78 \pm 0.06$. Therefore, the addition of $1.0 \mathrm{mmol} \mathrm{L}^{-1}$ of $\mathrm{Zn}$ obviated $\mathrm{Cu}$ toxicity on $\mathrm{M}$. maripaludis. This effect could be explained by the fact that $\mathrm{Cu}$ and $\mathrm{Zn}$ are both divalent cations, which often compete for the same transporter in many cell types. It could be expected that the addition of $\mathrm{Zn}$ to the medium retards $\mathrm{Cu}$ entry into the cell. In our study, $M$. maripaludis grew at concentrations of $\mathrm{Zn}$ that were 45 and 100 times higher than the concentration applied in growth experiments using $M$. marburgensis or $M$. barkeri, respectively [39]. This indicates a strong requirement for this metal by M. maripaludis.

\section{Propionate stimulates growth and $\mathrm{CH}_{4}$ production of $M$. maripaludis}

Different concentrations of acetate were used to stimulate or inhibit growth (Fig. 3a). The possible presence of an aceticlastic pathway in $M$. maripaludis was excluded by omitting $\mathrm{CO}_{2}$ and carbonate from the growth medium (see Figure S2 in Additional file 1). The results show that acetate cannot be the only source of carbon for $M$. maripaludis. Additionally, we examined whether propionate could stimulate or inhibit $M$. maripaludis growth (Fig. 3b), or whether propionate could replace acetate (Fig. 3c), as a potential source of carbon. Growth curves show a great similarity among the different concentrations of acetate and the maximum OD corresponds to a value about 1.25 (Fig. 3a). Growth curves at different 

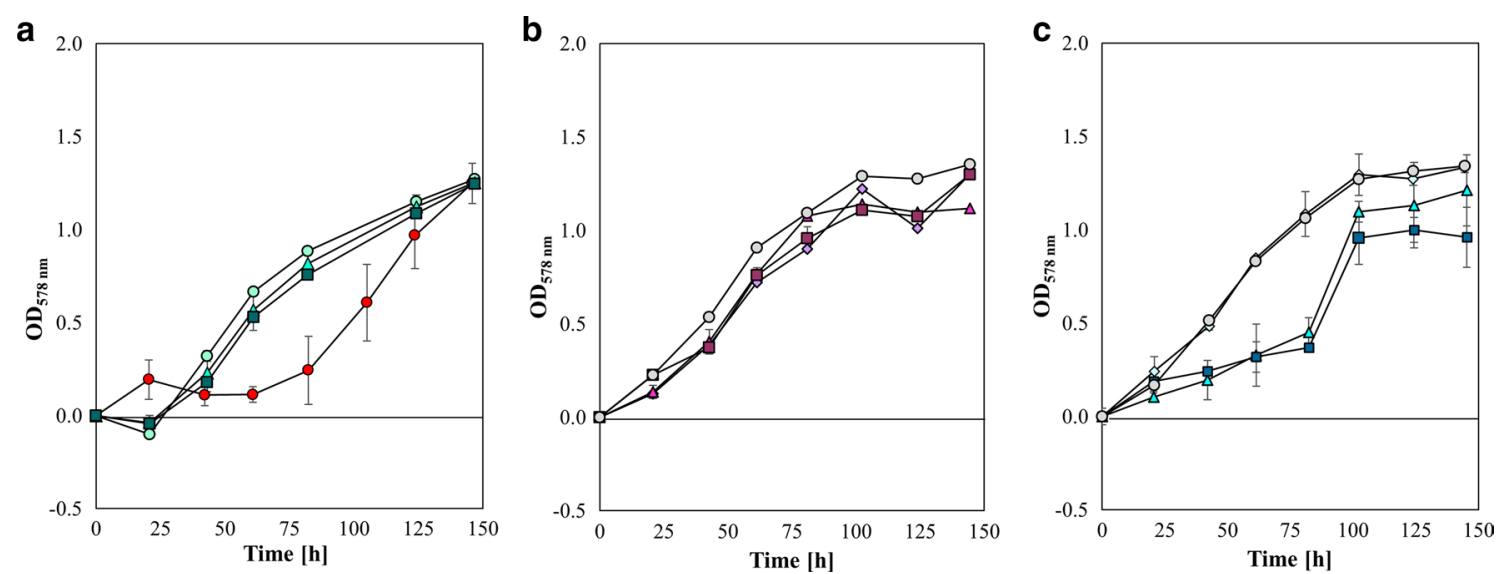

Fig. $3 \mathrm{OD}_{578 \mathrm{~nm}}$ of M. maripaludis $50 \mathrm{~mL}$ culture at $37^{\circ} \mathrm{C}, 140 \mathrm{rpm}, 2.9$ bar with acetate and without acetate, with propionate and acetate, with propionate only $(n=4)$. M. maripaludis was grown on: a $12.2 \mathrm{mmol} \mathrm{L}^{-1}$ as positive control $(n=3), 60.9 \mathrm{mmol} \mathrm{L}^{-1}$ of acetate $(\Delta), 121.9 \mathrm{mmol} \mathrm{L}{ }^{-1}$ of acetate ( $\boldsymbol{\square}$ ), without acetate ( $\bullet$ ); $\mathbf{b} 12.2 \mathrm{mmol} \mathrm{L}^{-1}$ of acetate as positive control $(\bullet, n=3), 12.2 \mathrm{mmol} \mathrm{L}^{-1}$ of acetate and $10.4 \mathrm{mmol} \mathrm{L}^{-1}$ of propionate $(\diamond), 60.9 \mathrm{mmol} \mathrm{L}^{-1}$ of acetate and $52.0 \mathrm{mmol} \mathrm{L}{ }^{-1}$ of propionate $(\Delta), 121.9 \mathrm{mmol} \mathrm{L}-1$ of acetate and $104.1 \mathrm{mmol} \mathrm{L}^{-1}$ of propionate ( 口); $\mathbf{c} 12.2 \mathrm{mmol} \mathrm{L}^{-1}$ of acetate and $10.4 \mathrm{mmol} \mathrm{L}^{-1}$ of propionate as positive control $(\bullet, n=3), 10.4 \mathrm{mmol} \mathrm{L}^{-1}$ of propionate $(\diamond), 52.0 \mathrm{mmol} \mathrm{L}^{-1}$ of propionate $(\Delta), 104.1 \mathrm{mmol} \mathrm{L}^{-1}$ of propionate $(\boldsymbol{\square})$

acetate concentrations are very similar to each other and reach the maximum OD of 1.25 (Fig. 3a). In the absence of acetate $(0 \mathrm{Ac})$, OD was found to reach similar final values but to substantially decrease through the time course, resulting in a longer lag phase. This observation is possibly due to the disruption of the correct metabolic operation, since acetate is an antimicrobial compound [50], and owns a key role as precursor of many cellular pathways supporting cellular homeostasis [51]. Although, $M$. maripaludis was still able to grow to the same final OD, the physiological potential of this microorganism was compromised due to acetate limitation. Intracellular acetate generation may be an explanation for $M$. maripaludis behaviour in the absence of acetate. M. maripaludis harbours genes for the ADP-forming acetyl-CoA synthetase (Acd; MMP0253) [52], also known as acetate-CoA ligase (ADP-forming), and the AMP-forming-type acetate-CoA synthetase (Acs; MMP0148) [51, 53]. The ADP-forming acetyl-CoA synthetase catalyses a reversible reaction, which is responsible for acetate formation and ATP synthesis from acetyl-CoA, ADP, and $\mathrm{P}_{\mathrm{i}}$ in halophilic archaea [54], and in hyperthermophilic archaea, i.e. Pyrococcus furiosus [55]. Despite that, an experimental demonstration of biosynthesis of acetate by $M$. maripaludis is missing. The addition of propionate to $\mathrm{m} 141$ medium did not compromise the growth of $M$. maripaludis at any concentrations (Fig. 3b). If acetate was not present in the medium, the growth curve followed the profile of the curve at $12.2 \mathrm{mmol} \mathrm{L}^{-1}$. However, when 60.9 and $121.9 \mathrm{mmol} \mathrm{L}^{-1}$ of acetate are replaced with 52.0 and $104.1 \mathrm{mmol} \mathrm{L}^{-1}$ of propionate in the medium (Fig. 3c),
M. maripaludis growth resulted in a retardation of biomass production over the first $81 \mathrm{~h}$ of incubation, thereafter exponential growth commenced. The shape of these growth curves resembled a sigmoidal curve which may indicated a putative growth inhibition of $M$. maripaludis due to the presence of propionate. This effect could be explained by an interfering of propionate with the proton $\left(\mathrm{H}^{+}\right)$gradient across the cell membrane. The diffusion of weak acids like propionate, as well as acetate, into the cell may cause a drop in intracellular $\mathrm{pH}$ due to exclusion of the anions and the retention of the $\mathrm{H}^{+}$which leads to uncoupling [56-59]. The excess of $\mathrm{H}^{+}$in the cytoplasm would have to be extruded out to preserve a functional electrochemical gradient. $\mathrm{H}^{+}$extrusion process requires ATP hydrolysis, causing a diminution in ATP availability. Consequently, acetate and propionate might act as "uncouplers" of the electrochemical gradient that affects the cellular homeostasis. Nevertheless, only propionate generated this peculiar growth curve suggesting that $M$. maripaludis needed an adaptation period before growth on propionate started. That may be ascribable to the presence of a specific mechanism of transport for acetate which also owns affinity for other carboxylic acids, such as propionate.

\section{The effect of VFAs and heavy metals on growth and $\mathrm{CH}_{4}$ production kinetics of $M$. maripaludis}

Given the distinct effect of $\mathrm{Cu}$ and $\mathrm{Zn}$ shown in Fig. 2, a series of closed batch experiments were performed to determine possible variations in the physiology of $M$. maripaludis with respect to acetate in combination with 
$\mathrm{Cu}$ or $\mathrm{Zn}$, respectively. As discussed before, the presence of $\mathrm{Zn}$ and $\mathrm{Cu}$ can alter the catalytic rate of ACS/ $\mathrm{CODH}$ complex, which is one of the two pathways used by $M$. maripaludis to synthetize acetyl-CoA. The other way is the AMP-forming acetyl-CoA synthetase (Acs) which is directly fuelled by acetate (Fig. 1). Although these two pathways are distinct, the combined supply of metals and acetate at higher concentrations may change the physiological response of $M$. maripaludis. Moreover, higher concentrations of VFAs may increase the uptake of metals into the cell. The growth curves resulting from these experiments are shown in Fig. 4. Despite the different acetate concentrations, the growth curves in Fig. 4a, b showed similar patterns. The reduction of biomass production compared to the positive controls (containing only 60.9 and $121.9 \mathrm{mmol} \mathrm{L}^{-1}$ of acetate) is directly dependent on increasing $\mathrm{Cu}$ concentration in the medium, but not on the concentration of acetate. This is also demonstrated by the similar values of the maximum OD which are $0.99 \pm 0.11$ (1Cu2Ac), $0.84 \pm 0.13$ (2Cu2Ac), $0.64 \pm 0.06$ (3Cu2Ac), $1.01 \pm 0.20$ (1Cu3Ac), $0.88 \pm 0.03$ (2Cu3Ac), $0.60 \pm 0.04$ (3Cu3Ac), respectively. Despite the presence of acetate, which supports growth via the ADP-forming acetyl-CoA synthetase, growth was compromised by the presence of rising $\mathrm{Cu}$ level which interferes with the ACS activity [46]. This may be an indication that the $\mathrm{CO}_{2}$-based acetyl-CoA production dominates over the acetate-based pathway even when a high concentration of acetate was available in the growth medium. Moreover, acetate can potentially form electron-neutral complexes with $\mathrm{Cu}$ as well as with $\mathrm{Zn}$, which make both organic acids and metals more permeable to the cell membrane. This could cause a certain level of toxicity [34]. Concerning the use of $1.0 \mathrm{mmol} \mathrm{L}^{-1}$ of $\mathrm{Zn}$ with increasing concentration of acetate (Fig. 4c), the response of $M$. maripaludis seems to be homogenous and independent of the acetate content. The maximum OD values are higher than 2 (Fig. 2a). Supposing that ACS is effectively targeted by $\mathrm{Cu}$ in $M$. maripaludis, excess acetate, the precursor of acetyl-CoA (Fig. 1), did not counteract the inactivity of the ACS. It could it be that the CODH/ ACS complex owns a prime role over the acetyl-CoA synthetase that is based on concomitant acetate and ATP consumption. However, the fact that acetate does not reduce $\mathrm{Cu}$ inhibition could also be seen as evidence against ACS as the primary target and it could be that other potential targets other than ACS are affected.

The kinetics of growth and $\mathrm{CH}_{4}$ production have been analysed and the results are presented in Fig. 5a, b. The impact of the different growth conditions that were experimentally addressed was less evident when $M E R_{\max }$ was examined than when specific growth rate $\left(\mu_{\max }\right)$
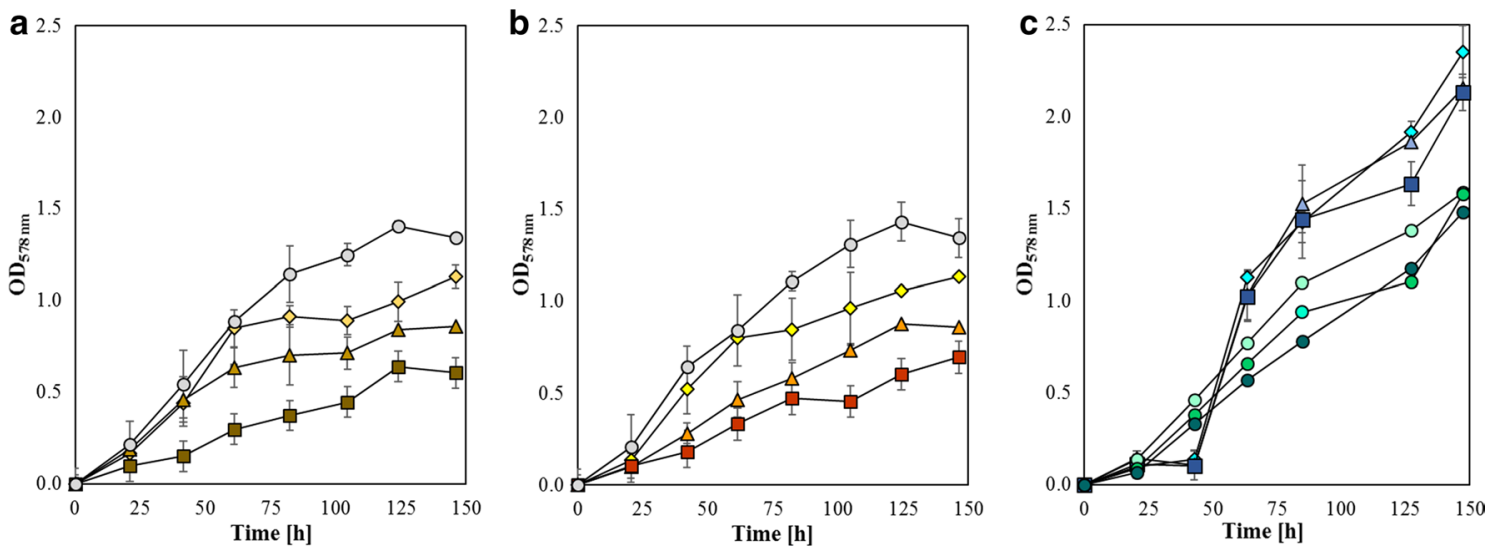

Fig. $4 \mathrm{OD}_{578 \mathrm{~nm}}$ curves of M. maripaludis $50 \mathrm{~mL}$ culture at $37^{\circ} \mathrm{C}, 140 \mathrm{rpm}, 2.9$ bar with acetate combined with Cu and $\mathrm{Zn}$, respectively $(n=4) . M$. maripaludis was grown on: a $60.9 \mathrm{mmol} \mathrm{L}-1$ of acetate only as positive control $(\bullet, n=3), 60.9 \mathrm{mmol} \mathrm{L}^{-1}$ of acetate with $1.9 \mu \mathrm{mol} \mathrm{L}^{-1}$ of $\mathrm{Cu}(\diamond)$, $4.4 \mu \mathrm{mol} \mathrm{L}{ }^{-1}$ of $\mathrm{Cu}(\boldsymbol{\Lambda})$ and $6.3 \mu \mathrm{mol} \mathrm{L}{ }^{-1}$ of $\mathrm{Cu}(\boldsymbol{\square}) ; \mathbf{b} 121.9 \mathrm{mmol} \mathrm{L} \mathrm{L}^{-1}$ of acetate only as positive control $(\boldsymbol{\bullet}, n=3), 121.9 \mathrm{mmol} \mathrm{L}^{-1}$ of acetate

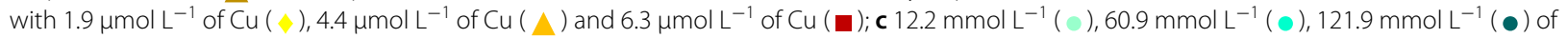

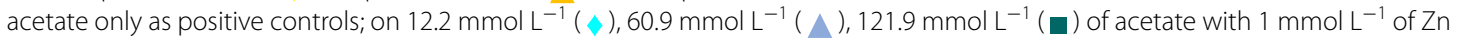

(See figure on next page.)

Fig. 5 Histograms of $\mathbf{a} \mu_{\max } \mathbf{b} \mathrm{MER}_{\max }$ and $\mathbf{c} \mathrm{qCH}_{4 \max }$ at each experimental condition applied in this study. M. maripaludis was grown at $37^{\circ} \mathrm{C}$, $140 \mathrm{rpm}, 2.9$ bar. Ac and Pr stand for acetate and propionate, respectively. The values 1, 2, 3 refer to the increasing concentrations of each compounds applied individually and simultaneously. $(1,2,3) \mathrm{Zn}: 1.0,2.4,3.9 \mathrm{mmol} \mathrm{L}^{-1} ;(1,2,3) \mathrm{Cu}: 1.9,4.4,6.3 \mu \mathrm{mol} \mathrm{L}{ }^{-1} ;(1,2,3)$ Ac: 12.2, 60.9, $121.9 \mathrm{mmol} \mathrm{L}^{-1},(1,2,3) \operatorname{Pr}: 10.4,52.0,104.1 \mathrm{mmol} \mathrm{L}^{-1}, 0 \mathrm{Ac}$ : without acetate 

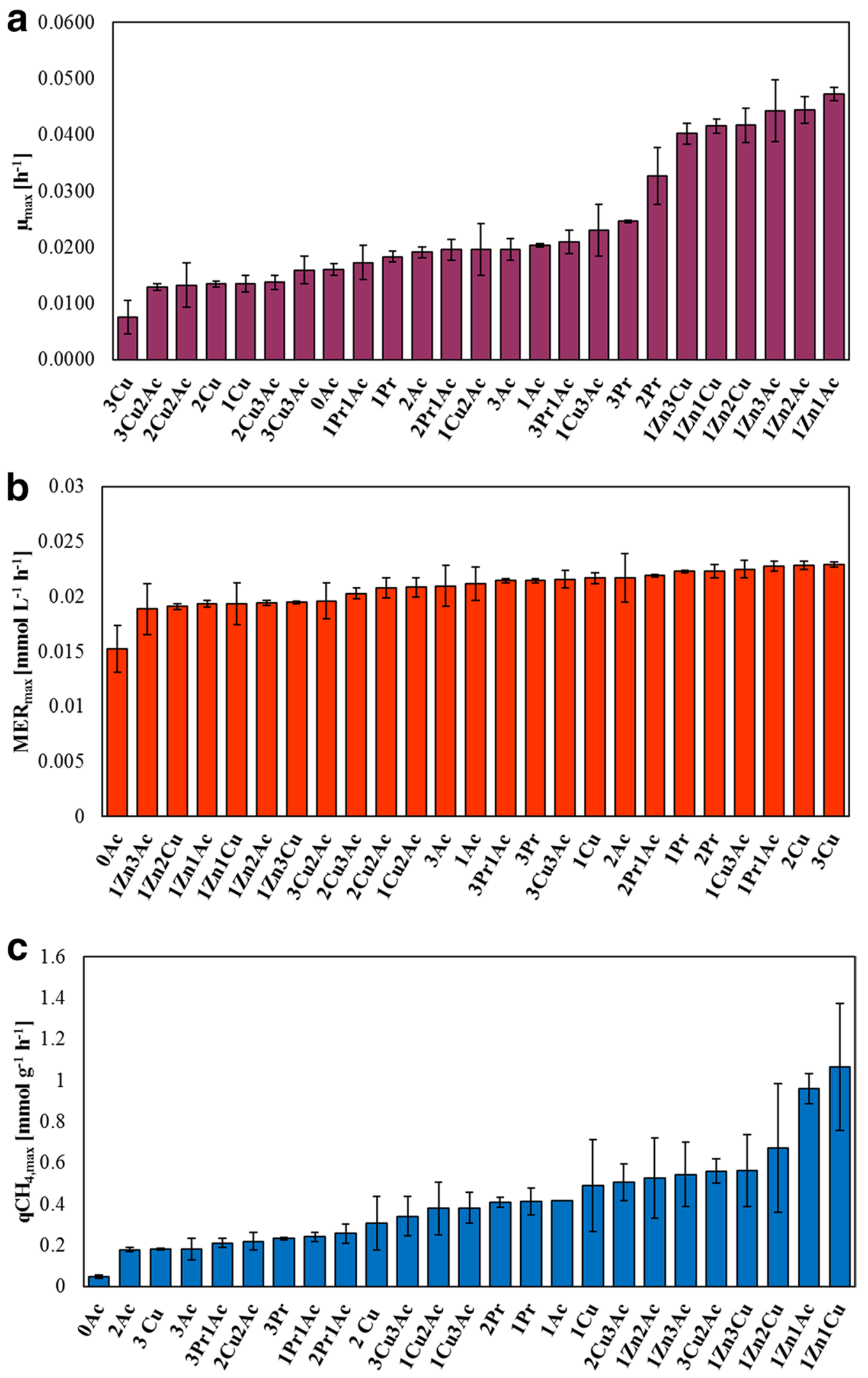
was analysed (Fig. 5a). As a general consideration, these results all together indicate that $\mathrm{Cu}, \mathrm{Zn}$, acetate, and propionate have a major influence on the central metabolism of $M$. maripaludis, but neither the individual nor the combination of these elements seriously affected growth and biological $\mathrm{CH}_{4}$ production. More precisely, $\mu_{\max }$ analysis highlighted a different physiological effect of the two metals in $M$. maripaludis. Indeed, the culture that grew at $6.3 \mu \mathrm{mol} \mathrm{L}{ }^{-1}$ of $\mathrm{Cu}$ showed the slowest growth $(0.0076 \pm 0.0029)$, while that grown at $1.0 \mathrm{mmol} \mathrm{L}^{-1}$ of $\mathrm{Zn}$ and 12.2 or 60.9 or $121.9 \mathrm{mmol} \mathrm{L}^{-1}$ of acetate showed $\mu_{\max }$ values more than double compared to the positive control $\left(0.0204 \pm 0.0003 \mathrm{~h}^{-1}\right)$. The deleterious effect of $\mathrm{Cu}$ could be due to the formation of a $\mathrm{Cu}-\mathrm{Ni}$ centre which produces an inactive form of ACS [40, 42, 60]. This inactivity is due to the poor nucleophilicity of $\mathrm{Cu}$ that prevents it from accepting the methyl group donated by the $\mathrm{H}_{4} \mathrm{MPT}$ from methanogenesis $[9,41]$. Also, $\mathrm{Zn}$ can bind to the metal centre of ACS and thus interfere with its proper enzymatic function [42]. However, the results of growth (OD and $\mu_{\max }$ ) indicated a different physiological effect of the two metals in M. maripaludis. Indeed, $\mathrm{Zn}$ did not inhibit growth of $M$. maripaludis, rather it enhanced it (Fig. 2a, 4c). The key to understand this difference may be that $\mathrm{Cu}$ does not only inhibit the ACS activity, but also that of $\mathrm{CODH}$, preventing the $\mathrm{CO}$ oxidation reaction, whereas $\mathrm{Zn}$ supposedly interfered with the methyl transfer [41]. Moreover, $\mathrm{Zn}$ can replace $\mathrm{Ni}$ in the ACS active site when the protein conformation is open, e.g. when the enzyme is already involved in catalysis [60-62]. One may speculate that the excess of $\mathrm{Zn}$ is physiologically balanced through the involvement in many enzymatic catalyses and affinity as metal cofactor such as the Hdr, Mtr, and RNA polymerase [28-32, 34, 35], which favour the growth of M. maripaludis, rather than negatively affecting it. The presence of higher concentration of acetate (2Ac and 3Ac) did not alter $\mu_{\max }$ compared to the positive control (1Ac) as expected on the base of the growth curves (Fig. 3a). The addition of propionate did not affect the $\mu_{\max }$ too, except for the cultures with 52.0 and $104.1 \mathrm{mmol} \mathrm{L}^{-1}$ (2Pr and 3Pr). Here, a sudden biomass accumulation after the $81 \mathrm{~h}$ was visible (Fig. 3c).

With respect to $\mathrm{CH}_{4}$ productivity, the highest values were observed for the positive control having a $\mathrm{MER}_{\max }$ value of $0.021 \pm 0.002 \mathrm{mmol} \mathrm{L}^{-1} \mathrm{~h}^{-1}$. The lowest productivity $\left(0.015 \pm 0.002 \mathrm{mmol} \mathrm{L}^{-1} \mathrm{~h}^{-1}\right)$ corresponds to the medium deprived of acetate $(0 \mathrm{Ac})$ while the highest values $\left(0.023 \mathrm{mmol} \mathrm{L}^{-1} \mathrm{~h}^{-1}\right)$ are represented by the cultures which were grown with 4.4 and $6.3 \mu \mathrm{mol} \mathrm{L}^{-1}$ of $\mathrm{Cu}(2 \mathrm{Cu}$ and $3 \mathrm{Cu}$ ). Therefore, under acetate deprivation, M. maripaludis can still proliferate and reach the maximum OD, but the kinetics of $\mathrm{CH}_{4}$ production was compromised.
Indeed, in the absence of acetate, the most easily accessible substrate for cell growth via acetyl-CoA production is $\mathrm{CO}_{2}$, but it needs to serve the combined carbon and energy metabolism of $M$. maripaludis. It may be possible that because of the competition between biomass generation and $\mathrm{CH}_{4}$ production, $\mu_{\max }$ and $\mathrm{MER}_{\max }$ became retarded. It is notable that all the cultures which have grown with $\mathrm{Zn}$-amended medium possess a $\mathrm{MER}_{\max }$ of $0.019 \mathrm{mmol} \mathrm{L}^{-1} \mathrm{~h}^{-1}$, which corresponds to a productivity reduction of $8-11 \%$ compared to the positive control (medium m141), in contrast to the elevated values of $\mu_{\max }$ (Fig. 5a). This finding confirmed the crucial role of $\mathrm{Zn}$ in supporting cell growth on one side and indicates a probable inhibitory effect on methanogenesis on the other side. A possible explanation may be found in the interference of $\mathrm{Zn}$ abundance with more than one enzyme involved in the methanogenesis, e.g. the $\mathrm{Hdr}$ and Mtr. Indeed, the intermediate of methanogenesis, the methyl- $\mathrm{H}_{4} \mathrm{MPT}$, which is transferred by Mtr to the $\mathrm{CoM}$, is the source of the methyl group of acetyl-CoA during $\mathrm{CO}_{2}$ fixation. Therefore, the abundance of $\mathrm{Zn}$ may alter the equilibrium concentration in the mechanism that regulates the destiny of methyl- $\mathrm{H}_{4} \mathrm{MPT}$ in one direction rather than the other. The effect of $\mathrm{Cu}(1.9,4.4$, and $6.3 \mu \mathrm{mol} \mathrm{L}^{-1}$ ) on $\mathrm{MER}_{\max }$ is almost homogenous at each concentration. However, when $\mathrm{Cu}$ was combined with acetate, the productivity decreased compared to the positive control (medium m141). Although the reason this occurs is not clear yet, a possible explanation for this may be the formation of $\mathrm{Cu}$-acetate aggregates which make $\mathrm{Cu}$ more easily available for the microorganism [34]. Thus, also the effect of $\mathrm{Cu}$ would be intensified when driven by acetate through the cell membrane. Figure $5 \mathrm{C}$ shows that $\mathrm{qCH}_{4, \max }$ values are due to the fluctuation of biomass concentration under different experimental conditions, since $\mathrm{MER}_{\max }$ values are rather constants. Moreover, $\mathrm{qCH}_{4, \max }$ profile is similar to the $\mu_{\max }$ profile (Fig. 5a). The 0Ac sample owns the lowest value of $\mathrm{qCH}_{4, \max }\left(0.047 \pm 0.009 \mathrm{mmol} \mathrm{g}^{-1} \mathrm{~h}^{-1}\right)$, which confirms that the catalytic power of $M$. maripaludis is heavily influenced when deprived of acetate. On the contrary, $\mathrm{qCH}_{4, \max }$ was maximized by the presence of $1 \mathrm{mmol} \mathrm{L}^{-1}$ of $\mathrm{Zn}$ was in the medium (1Zn1Ac and $1 \mathrm{Zn} 1 \mathrm{Cu}$ ), achieving values of $0.96 \pm 0.07$ and $1.07 \pm 0.31 \mathrm{mmol} \mathrm{g}^{-1} \mathrm{~h}^{-1}$. Thus, the beneficial effect of $\mathrm{Zn}$ on M. maripaludis growth (Fig. 2a) improved also its $\mathrm{qCH}_{4}$. Increasing the concentrations of $\mathrm{Cu}(1 \mathrm{Cu} 1.9,2 \mathrm{Cu}$ 4.4, and $\left.3 \mathrm{Cu} 6.3 \mu \mathrm{mol} \mathrm{L}^{-1}\right)$ led to decreasing $\mathrm{qCH}_{4, \max }$ values $\left(0.49 \pm 0.22 ; 0.31 \pm 0.13 ; 0.181 \pm 0.004 \mathrm{mmol} \mathrm{g}^{-1}\right.$ $\mathrm{h}^{-1}$, respectively, Fig. 5c). The high susceptibility of $M$. maripaludis to this metal is proved again by these results. The effect of propionate on $\mathrm{qCH}_{4, \max }$ is strictly connected to the concentration in the sample. $\mathrm{qCH}_{4, \max }$ 
assumed similar values among the different concentration of acetate, indicating that this parameter is not dependent on the acetate concentration.

\section{Analysis of acetate and propionate uptake by $M$. maripaludis}

The values reported in Table 1 prove that both acetate and propionate are consumed among the different samples, with some exceptions represented by $1 \mathrm{Pr}$. The HPLC analysis of acetate and propionate levels was performed at the end of the closed batch experiments. Although in $1 \mathrm{Pr}$, acetate is supposed to be zero, the analysis revealed a concentration equal to $1.39 \pm 0.27 \mathrm{mmol}$ acetate $\mathrm{L}^{-1}$ in respect of $0.34 \mathrm{mmol}$ acetate $\mathrm{L}^{-1}$ in the negative control (sample containing medium only). These data may support the hypothesis of endogenous acetate synthesis by the ADP-forming acetyl-CoA synthetase of $M$. maripaludis [52]. However, also 2Pr1Ac shows a value of acetate that is higher than the acetate content in the negative control. This is the only exception among the experiments where propionate was combined with acetate. Therefore, this deviation may be explained by a lower injection of acetate in the negative control sample during culture preparation. On the basis of these data, acetate synthesis would seem to be stimulated by the absence of acetate $(1 \mathrm{Pr})$ and it may explain the growth curve in Fig. 3c, which is almost the same of the curve corresponding to $12.2 \mathrm{mmol} \mathrm{L}^{-1}$ of acetate. Unfortunately, HPLC analyses of $2 \mathrm{Pr}$ and $3 \mathrm{Pr}$, which show a different behaviour of $M$. maripaludis growth (Fig. 3c), were not available. Hence, we do not know if endogenous acetate production occurred at higher concentration of propionate, or if propionate may interfere with it given the longer lag phase (Fig. 3c). The graphical representation of Table 1 is illustrated in Fig. 6. By increasing acetate concentration in the medium from 12.2 to $121.9 \mathrm{mmol} \mathrm{L}^{-1}$, the absorbed concentration raised from $0.62 \pm 0.04$ to $2.41 \pm 0.43 \mathrm{mmol} \mathrm{L}^{-1}$ respect to the negative control (Fig. 6). Despite these results, growth curves, $\mu$, and MER are very similar among the different concentrations of acetate (Figs. 3a, 5a, b). The undissociated form of VFAs should be rather low compared to the anionic form at $\mathrm{pH} \geq 8$. Therefore, an increased acetate uptake may be regulated by a specific transport reaction. However, the amount of acetate that was assimilated is quite low and not even close to the $60 \%$ of extracellular acetate which would be possible to be assimilated [32]. Concerning propionate, the results indicate that $M$. maripaludis can recover this organic acid (1Pr1Ac, 2Pr1Ac, 3Pr1Ac), although the consumed concentrations are quite low compared to acetate, and the high standard deviations indicate a great variability among the replicates of this experiment. Moreover, as already mentioned above, the negative bar in $1 \mathrm{Pr}$ may be an indication of a possible acetate extrusion by $M$. maripaludis cells. $\mathrm{Cu}$ concentrations in $2 \mathrm{Cu} 2 \mathrm{Ac}$ and $3 \mathrm{Cu} 2 \mathrm{Ac}$ led to a reduction of acetate assimilation (Fig. 6). Interestingly, the same concentrations of $\mathrm{Cu}$ did not affect the recovery of acetate in 2Cu3Ac and 3Cu3Ac samples, which have similar values of acetate consumption. The data on acetate consumption in the presence of $\mathrm{Cu}$ are discordant among the different measurements. A possible explanation may be the formation of metal-acid aggregates that can enter the cell, which would improve at higher concentration of $\mathrm{Cu}$

Table 1 Analysis of acetate (Ac) and propionate (Pr) concentrations at the end of each experiment

\begin{tabular}{|c|c|c|c|c|}
\hline Sample & $-\mathrm{C}\left(\mathrm{mmol}_{\mathrm{Ac}} \mathrm{L}^{-1}\right)$ & $A c\left(\mathrm{mmol}_{A c} \mathrm{~L}^{-1}\right)$ & $-\mathrm{C}\left(\mathrm{mmol}_{\mathrm{Pr}} \mathrm{L}^{-1}\right)$ & $\operatorname{Pr}\left(\mathrm{mmol}_{\mathrm{Pr}} \mathrm{L}^{-1}\right)$ \\
\hline $1 \mathrm{Ac}$ & 9.81 & $9.19 \pm 0.04$ & na & na \\
\hline $2 A C$ & 48.34 & $46.47 \pm 2.48$ & na & na \\
\hline $3 A C$ & 85.74 & $82.43 \pm 1.84$ & na & na \\
\hline 1PrOAC & 0.34 & $1.39 \pm 0.27$ & 9.96 & $9.82 \pm 0.49$ \\
\hline $1 \operatorname{Pr} 1 A C$ & 9.81 & 9.18 & 9.96 & 8.43 \\
\hline 2Pr1Ac & 8.92 & $10.39 \pm 1.00$ & 41.04 & $38.71 \pm 0.67$ \\
\hline $3 \operatorname{Pr} 1 A C$ & 10.69 & $9.43 \pm 0.57$ & 75.48 & $72.51 \pm 2.02$ \\
\hline $1 \mathrm{Cu} 2 \mathrm{Ac}$ & 47.63 & $41.40 \pm 1.02$ & na & na \\
\hline $2 \mathrm{Cu} 2 \mathrm{Ac}$ & 44.47 & $41.60 \pm 1.58$ & na & na \\
\hline $3 \mathrm{Cu} 2 \mathrm{Ac}$ & 43.85 & $41.98 \pm 0.65$ & na & na \\
\hline $1 \mathrm{Cu} A \mathrm{Ac}$ & 84.77 & $77.72 \pm 1.27$ & na & na \\
\hline $2 \mathrm{Cu} 3 \mathrm{Ac}$ & 84.16 & $76.08 \pm 1.94$ & na & na \\
\hline $3 \mathrm{Cu} 3 \mathrm{Ac}$ & 85.37 & $77.38 \pm 2.29$ & na & na \\
\hline
\end{tabular}

Batch cultivations of $M$. maripaludis were performed at $37^{\circ} \mathrm{C}, 140 \mathrm{rpm}, 2.9$ bar. The values $1,2,3$ refer to the increasing concentrations of each compounds applied individually and simultaneously. $\left.(1,2,3) \mathrm{Ac}: 12.2,60.9,121.9 \mathrm{mmol} \mathrm{L}^{-1} ;(1,2,3) \mathrm{Pr}: 10.4,52.0,104.1 \mathrm{mmol} \mathrm{L}^{-1} 12.2,60.9,121.9 \mathrm{mmol} \mathrm{L}^{-1} ; \mathrm{Cu}^{(1.9,4.4,6.3 \mu \mathrm{mol} \mathrm{L}}{ }^{-1}\right)$. The negative control $(-c)$ refers to medium that did not receive inoculum of cells and therefore is used as a reference value

na not applied 


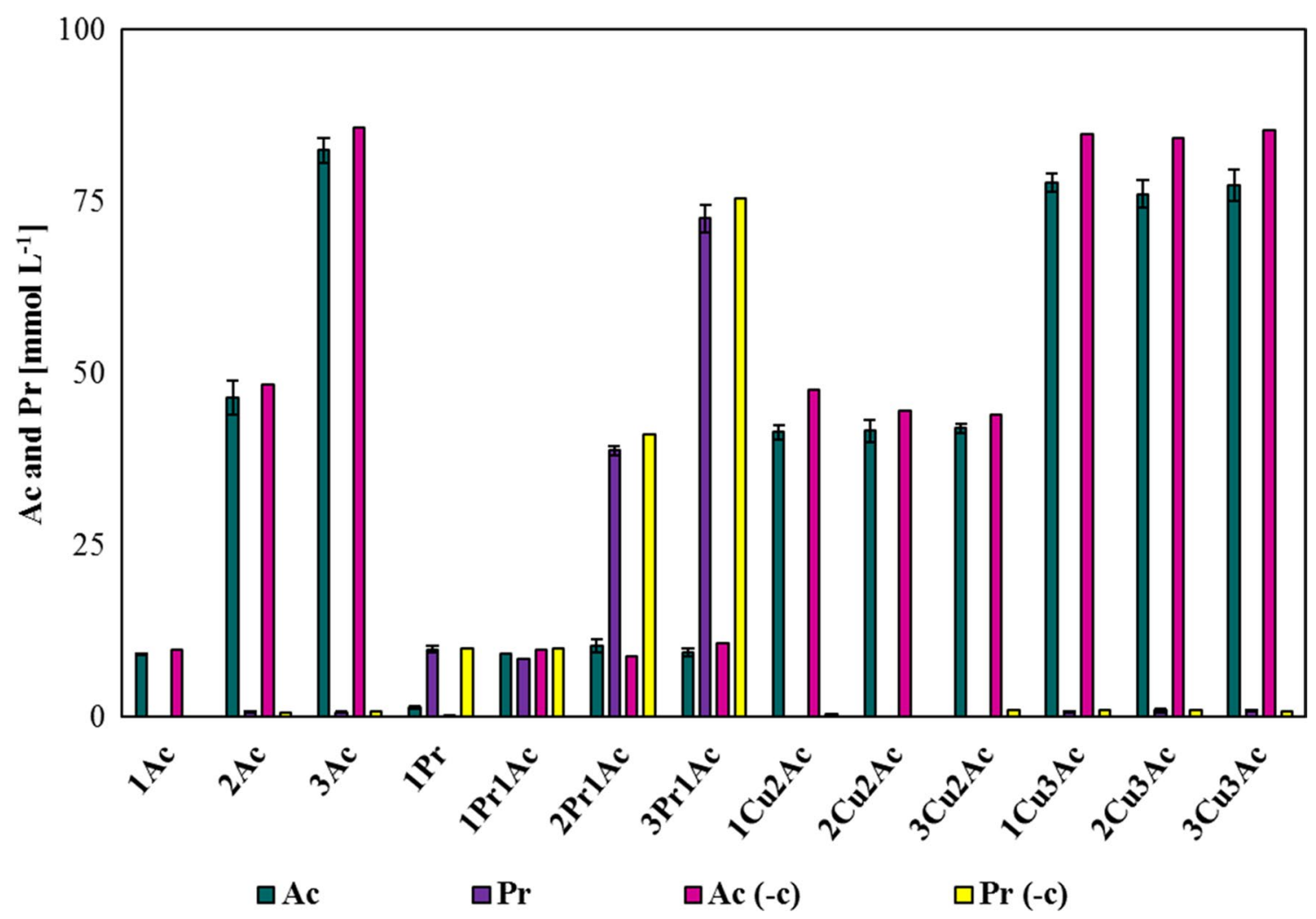

Fig. 6 Concentration of acetate (Ac) and propionate (Pr) measured at the end of the closed batch cultivation of M. maripaludis $37^{\circ} \mathrm{C}, 140 \mathrm{rpm}$, 2.9 bar. The values $1,2,3$ refer to the increasing concentrations of each compounds applied individually and simultaneously. $(1,2,3)$ Ac: $12.2,60.9$, $121.9 \mathrm{mmol} \mathrm{L}^{-1} ;(1,2,3) \operatorname{Pr}: 10.4,52.0,104.1 \mathrm{mmol} \mathrm{L}^{-1} 12.2,60.9,121.9 \mathrm{mmol} \mathrm{L}^{-1} ; \mathrm{Cu}\left(1.9,4.4,6.3 \mu \mathrm{mol} \mathrm{L}^{-1}\right)$

and acetate or the complexation of elements and organic acids with sulphide. However, this marked difference is not consistent with the results of OD, $\mu_{\max }$, and $\mathrm{MER}_{\max }$ that were rather similar at 60.9 and $121.9 \mathrm{mmol} \mathrm{L}^{-1}$.

\section{Mechanism of acetate transport into M. maripaludis}

It is of general interest to discuss the possible mode of action of acetate transport into the cytoplasm. Acetate is a strong protonophore which can readily diffuse into the cytoplasm even in dissociated form, if the $\mathrm{pH}$ is $\geq 7$ $[58,59]$. Evidence of acetate transport proteins has been shown in Saccharomyces cerevisiae [63] and E. coli [64], where the presence of these enzymes enhanced the acetate uptake. In S. cerevisiae, the Ady $2 p$ transmembrane protein was identified as responsible for acetate uptake when the cell was subjected to a shift from glucose to acetate. Acetate transport in E. coli is based on the Yahh protein. Yahh acts as an acetate-proton symporter, which is dependent on the transmembrane electrochemical potential. Moreover, Yahh is also able to recognize and uptake succinic acid though with a low affinity. Both Ady2p and Yahh belong to the GPR1/FUN34/SatP acetate transporter family. The knowledge about acetate transport into archaeal microorganism is poor. A pioneering study on this topic was performed with Methanosarcina mazei [65]. In this context, the role of $m m_{-} 0903$ (Q8PYF9) gene in aceticlastic methanogenesis was shown and the relevance of this protein in settling the acetate threshold level in Methanosarcina spp. was hypothesized. Homologues to the MM_0903 protein were found also in non-aceticlastic methanogens, usually with an identity lower than 67\% [65]. Although the present study does not specifically focus on acetate assimilation, we sought to identify a possible mechanism of transport in M. maripaludis which can explain the differences in acetate uptake, as evidenced in Fig. 6. The Blast search for MM_0903 resulted in 250 alignments, where 71 protein sequences corresponded to the archaeal domain. Among them, the GPR1/FUN34/YaaH family protein belonging to Methanococcus vannielii (Mevan_1357, A6URY2), matched MM_0903 with $60.8 \%$ of identity and an $E$-value of $3.8 \mathrm{e}-74$. Therefore, by restricting the search for alignments to this methanococci related class, we were able to identify a matching protein sequence (identity of $80.3 \%, E$-value of $1.48 \mathrm{e}-101$ ) corresponding to mmp0348 gene (Q6M0C3). MMP0348 corresponds to 
an uncharacterized protein of 197 amino acids belonging to $M$. maripaludis. Putative conserved domain on this sequence corresponds to the acetate transporter GPR1/ FUN34/SatP evolutionary family belonging to Candida lipolytica, S. cerevisiae, E. coli, and Aspergillus nidulans. MMP0348 protein shows a very high domain-specific alignment ( $E$-value of $3.71 \mathrm{e}-72)$ with SatP protein. SatP is associated to the succinate-acetate transport function in E. coli $\mathrm{O} 157: \mathrm{H} 7$ and MMP0348 revealed a 59\% of identity of the sequences (see Additional file 2: Figure S3). Protein structural models of SatP and the hypothetical acetate transport protein MMP0348 of M. maripaludis S2 are illustrated in Fig. 7 [66-70]. The highest quality model for SatP protein with a $P$-value of $8.4 \mathrm{e}-06$ is based on a succinate-acetate permease from Citrobacter koseri (see Additional file 2: Table S1) [71]. The best MMP0348 structure model was designed on a membrane protein for ammonium sensing (Amt protein template 6eu6A), which was also found among the selected templates for building SatP model (See Additional file 2: Table S1).

As for GPR1/FUN34/SatP family [63], also MMP0348 protein contains six transmembrane regions (Fig. 7) that may be involved in acetate transport. Moreover, MMP0348 protein is supposed to interact with MMP1274 (AMP-dependent synthetase and ligase) and MMP0148 or acsA (AMP-forming ACS) [72], but MM0348 was not yet biochemically characterized. The nature of these interactions is not clear since the presence of a unique gene cluster it has not been shown, but it is only a possibility based on homologous genes. However, if confirmed, the hypothetical acetate transporter (MMP0348) may act also as a precursor of acetyl-coA synthesis based on acetate. Supposing that, MMP0348 in $M$. maripaludis works as YaaH in E. coli [64], each molecule of acetate is co-translocated with $\mathrm{H}^{+}$. The result of this mechanism is the same as when acetic acid diffuses across the membrane and dissociates into acetate and the $\mathrm{H}^{+}$. The YaaH transporter can transport a broad range of substrates, e.g. borate, oxalate, pyruvate, lactate, malate, citrate, succinate, and acetate. However, formate, propionate, benzoate, salicylate, and butyrate were shown to possess an inhibitory effect $(>80 \%)$ on acetate uptake [64]. This suggested that all salts of the monocarboxylic acids acted as non-competitive inhibitors of acetate uptake in E. coli. Given the homology between YaaH and MMP0348, it is probable that there is a similar mechanism in M. maripaludis. Thus, it is possible to speculate about the reversible inhibition of propionate on cell growth because of the binding to MMP0348. This may explain the growth curves shape of $2 \mathrm{Pr}$ and $3 \mathrm{Pr}$ in Fig. 3c. As a non-competitive inhibitor, propionate could bind to the MMP0348 and enter the cell via the specific transport system. Furthermore, the analysis of $\mathrm{mm0348}$ gene expression and also the biochemical characterization of this putative transporter are nevertheless required to shed light on the possible interactions of MM0348 with the acetyl-CoA synthetase, and to prove its role in acetate and propionate uptake in M. maripaludis.

\section{Conclusions}

The physiological effect of $\mathrm{Cu}$ and $\mathrm{Zn}$, acetate, and propionate on $M$. maripaludis was examined. Differently from $\mu$ and $\mathrm{qCH}_{4}$, MER was not influenced by the presence of these compounds. This indicated that each of these compounds directly interacted with the C-fixation machinery of $M$. maripaludis. Interestingly, high $\mathrm{Zn} \mathrm{lev-}$ els $\left(1 \mathrm{mmol} \mathrm{L}^{-1}\right)$ enhanced growth of $M$. maripaludis and mitigated the toxicity of $\mathrm{Cu}$. Furthermore, as an alternative to acetate, propionate can be assimilated by M. maripaludis. Until now, the uptake of VFAs other than acetate, was not considered to be able to enhance growth and $\mathrm{CH}_{4}$ production of methanogens. The finding

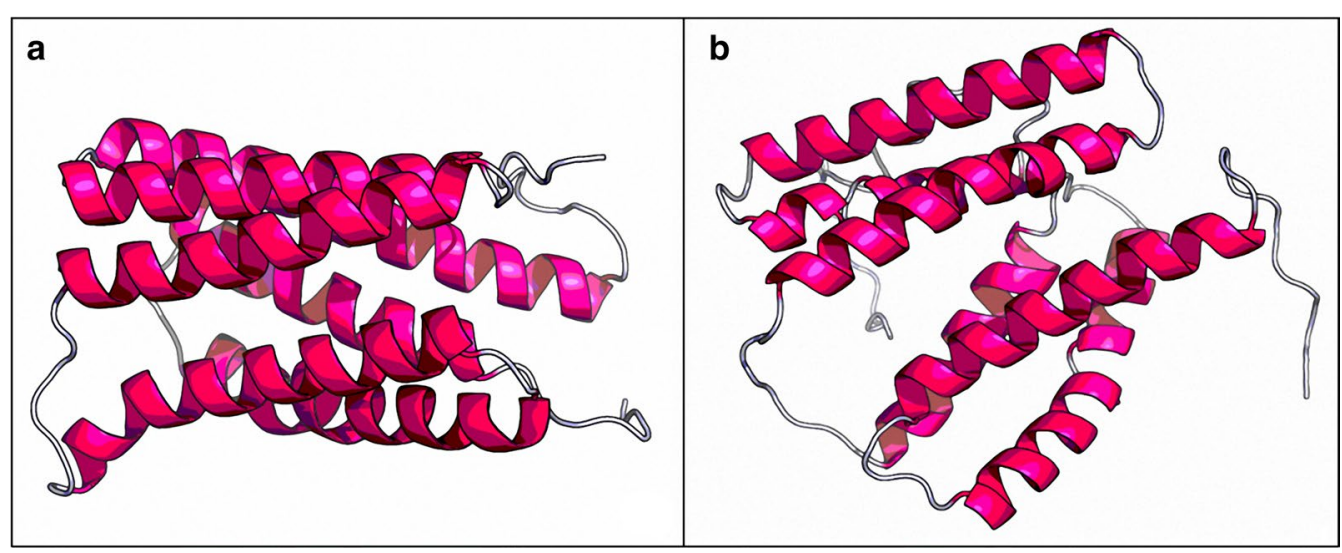

Fig. 7 3-D model structure of a SatP and $\mathbf{b}$ MMP0348 based on their amino acid sequence (from RaptorX server) 
of propionate uptake by $M$. maripaludis is also important for the interpretation of VFA cycling in anaerobic microenvironments. Moreover, we propose a specific acetate transporter of $M$. maripaludis. However, the acetate transporter, which could possibly also be considered to act as propionate transporter, was only identified by using in silico analyses of the unclassified MM0348 protein. Our study attempted to shed light on the physiological effect of VFAs and heavy metals on M. maripaludis, but due to the importance of methanogens in natural and artificial anaerobic environments, our findings have implications for understanding the ecophysiology and $\mathrm{CH}_{4}$ production characteristics of these intriguing organisms.

\section{Methods}

\section{Gases and chemicals}

The gases, $\mathrm{H}_{2} / \mathrm{CO}_{2}\left(20 \mathrm{Vol}\right.$.\% $\mathrm{CO}_{2}$ in $\mathrm{H}_{2}$ ) and molecular nitrogen $\left(\mathrm{N}_{2}\right)$, were from Air Liquide (Air Liquide $\mathrm{GmbH}$, Schwechat, Austria). All other chemicals were of highest grade available.

\section{Culture preparation and maintenance}

The mesophilic, autotrophic, hydrogenotrophic, and methanogenic organism Methanococcus maripaludis S2 [53] was used in all experiments. The methanogenium medium 141 DSMZ was modified as follows: $0.014 \mathrm{mg} \mathrm{L}^{-1}$ of $\mathrm{FeSO}_{4} \cdot 7 \mathrm{H}_{2} \mathrm{O}$ instead of $2 \mathrm{~mL}$ $\mathrm{Fe}\left(\mathrm{NH}_{4}\right)_{2}\left(\mathrm{SO}_{4}\right)_{2} \cdot 6 \mathrm{H}_{2} \mathrm{O}$, trypticase peptone, resazurin, and vitamins solutions were omitted from the medium. Trace element (TE) solution 141 DSMZ was prepared with the following modifications: instead of $0.500 \mathrm{~g} \mathrm{~L}^{-1}$ $\mathrm{MnSO}_{4} \cdot \mathrm{H}_{2} \mathrm{O}, 0.585 \mathrm{~g} \mathrm{~L}^{-1}$ of $\mathrm{MnCl}_{2} \cdot 4 \mathrm{H}_{2} \mathrm{O}$ were used, and both, $\mathrm{CuSO}_{4}$ and $\mathrm{ZnSO}_{4} \cdot 7 \mathrm{H}_{2} \mathrm{O}$ were omitted from the solution. The modified medium (named as m141) was prepared and autoclaved in 1-L bottle and closed with a screw cap comprising three ports $\left(\right.$ Duran $^{\circledR}$, GL 45 blue PP screw cap with $3 \times$ GL 14 ports). A stock solution of $0.11 \mathrm{~mol} \mathrm{~L}^{-1} \mathrm{Na}_{2} \mathrm{~S} \cdot 9 \mathrm{H}_{2} \mathrm{O}$ was prepared and autoclaved in the aforementioned system. $2.38 \mathrm{~mol} \mathrm{~L}^{-1}$ $\mathrm{NaHCO}_{3}$ and $0.059 \mathrm{~mol} \mathrm{~L}{ }^{-1}$ L-cysteine- $\mathrm{HCl} \cdot \mathrm{H}_{2} \mathrm{O}$ were prepared separately in $120 \mathrm{~mL}$ serum bottles (La-PhaPack, Langerwehe, Germany) as stock solutions, sealed, and deoxygenated by flushing them with $\mathrm{N}_{2}$ in a pressure range of $0.8-1.0 \mathrm{bar}$. All solutions were sterilized through autoclaving for $20 \mathrm{~min}$ at $121^{\circ} \mathrm{C}$.

\section{Closed batch cultures preparation}

The autoclaved media were amended with $10 \mathrm{~mL}$ of TE solution and then purged through a filter with $\mathrm{N}_{2}$ to make it anoxic for $40 \mathrm{~min} .50 \mathrm{~mL}$ of $\mathrm{NaHCO}_{3}$ stock solution, $5 \mathrm{~mL}$ of $\mathrm{L}$-cysteine- $\mathrm{HCl} \cdot \mathrm{H}_{2} \mathrm{O}$ stock solution, and $18.75 \mathrm{~mL} \mathrm{Na}_{2} \mathrm{~S} \cdot 9 \mathrm{H}_{2} \mathrm{O}$ stock solution were then added by using stile syringes. The medium was then dispensed in $120 \mathrm{~mL}$ serum bottles (La-Pha-Pack, Langerwehe, Germany) that were previously flushed with $\mathrm{N}_{2}$ to remove residual oxygen, and then inoculated using $1 \mathrm{v} / \mathrm{v}$ of fresh culture, for a final volume of $50 \mathrm{~mL}$ per flask. All experiments were carried out in quadruplicates with one negative control (sample containing medium only) and one positive control (reference sample). Above-described operations were all performed inside a laminar flow (LaminAir ${ }^{\circledR}$ HB 2472, Heraeus Instruments, Hallbergmoos, Germany). Immediately after inoculation, the bottles were pressurized with a $\mathrm{H}_{2} / \mathrm{CO}_{2}$ gas mixture between 2.7 and 3.1 bar as previously described [73]. Sterile syringe filters (w/0.2 cm cellulose, 514-0061, VWR International, USA), disposable hypodermic needles $(\mathrm{Gr}$ $14,0.80 \times 40 \mathrm{~mm}, 21 \mathrm{G} \times 11 / 2^{\prime \prime}, 80 \times 25 \mathrm{~mm}, 21 \mathrm{G} \times 1^{\prime \prime}$, Henke-Sass Wolf GmbH, Tuttlingen, Germany), and stopcocks (4-way with luer lock connections and male lock, Cole-Parmer, Illinois, United States) were used for feeding the cultures. After gassing, the flasks were incubated at $37{ }^{\circ} \mathrm{C}$ and $140 \mathrm{rpm}$ (Multitron, Infors HT, Basel, Switzerland and Innova ${ }^{\circledR}$ 44, Eppendorf AG, Hamburg, Germany). The headspace pressure in the serum bottles was measured daily using a digital manometer (2086P, 1-10 bar, Digitron, Italy). Residual $\mathrm{CH}_{4}$ was replaced every day by releasing the offgas and gassing the serum bottle headspace with $\mathrm{H}_{2} / \mathrm{CO}_{2}$ at a pressure between 2.7 and 3.1 bar. A volume between 0.9 and $1.1 \mathrm{~mL}$ of liquid sample was collected by using sterile syringes at regular intervals for monitoring biomass growth by measuring the optical density at $578 \mathrm{~nm}\left(\mathrm{OD}_{578}\right)$ using a spectrophotometer (DR $2800^{\mathrm{TM}}$ Portable Spectrophotometer, Hach, Australia). Every sampling operation was done inside the laminar. A summary of experiments performed within the frame of this study is shown in Table 2.

\section{Test with Cu or $\mathrm{Zn}$}

Three different concentrations of $\mathrm{Zn}$, provided as $\mathrm{ZnSO}_{4} \cdot 7 \mathrm{H}_{2} \mathrm{O}\left(1.04,2.4\right.$, and $\left.3.5 \mathrm{mmol} \mathrm{L}^{-1}\right)$ and $\mathrm{Cu}$, provided as $\mathrm{CuSO}_{4}\left(1.9,4.4,6.3 \mu \mathrm{mol} \mathrm{L}{ }^{-1}\right)$ were used for investigating the physiology and $\mathrm{CH}_{4}$ productivity of $M$. maripaludis (Table 2, 1-6). Therefore, two liquid stock solutions were prepared: (I) $0.17 \mathrm{~mol} \mathrm{~L}^{-1} \mathrm{ZnSO}_{4} \cdot 7 \mathrm{H}_{2} \mathrm{O}$ $\mathrm{M}$, (II) $63 \mathrm{mmol} \mathrm{L}^{-1} \mathrm{CuSO}_{4}$. After dispensing the $\mathrm{m} 141$ medium in each bottle, appropriate volumes of $\mathrm{Zn}$ or $\mathrm{Cu}$ were added to the replicates and to the negative control.

\section{Test with acetate and propionate}

Two concentrations of sodium acetate (60.9 and $121.9 \mathrm{mmol} \mathrm{L}^{-1}$ ) were tested in addition to the recommended concentration of $12.2 \mathrm{mmol} \mathrm{L}^{-1}[74,75]$ in methanogenium medium 141 (DSMZ GmbH, Germany) (Table 2, 7-9). In addition, closed batch experiments 
Table 2 Type of compounds used as potential inhibitors and its corresponding concentrations

\begin{tabular}{|c|c|c|c|}
\hline Inhibitor type & $\#$ & Sample name & Compound and concentration \\
\hline \multirow[t]{6}{*}{ Inorganic ${ }^{a}$} & 1 & $1 \mathrm{Zn}$ & $\mathrm{Zn} 1.0 \mathrm{mmol} \mathrm{L}-1$ \\
\hline & 2 & $2 Z n$ & Zn $2.4 \mathrm{mmol} \mathrm{L}^{-1}$ \\
\hline & 3 & $3 Z n$ & Zn 3.9 mmol L-1 \\
\hline & 4 & $1 \mathrm{Cu}$ & Cu $1.9 \mu \mathrm{mol} \mathrm{L}^{-1}$ \\
\hline & 5 & $2 \mathrm{Cu}$ & $\mathrm{Cu} 4.4 \mu \mathrm{mol} \mathrm{L}-1$ \\
\hline & 6 & $3 \mathrm{Cu}$ & Cu $6.3 \mu \mathrm{mol} \mathrm{L}^{-1}$ \\
\hline \multirow[t]{9}{*}{ Organic and organic/organic } & 7 & $1 \mathrm{Ac}$ & Ac $12.2 \mathrm{mmol} \mathrm{L}^{-1}$ \\
\hline & 8 & $2 \mathrm{Ac}$ & Ac $60.9 \mathrm{mmol} \mathrm{L}^{-1}$ \\
\hline & 9 & $3 A C$ & Ac $121.9 \mathrm{mmol} \mathrm{L}^{-1}$ \\
\hline & 10 & $1 \mathrm{Pr}$ & $\operatorname{Pr} 10.4 \mathrm{mmol} \mathrm{L}^{-1}$ \\
\hline & 11 & $2 \mathrm{Pr}$ & $\operatorname{Pr} 52.0 \mathrm{mmol} \mathrm{L}^{-1}$ \\
\hline & 12 & $3 \mathrm{Pr}$ & $\operatorname{Pr} 104.1 \mathrm{mmol} \mathrm{L}^{-1}$ \\
\hline & 13 & $1 \operatorname{Pr} 1 A C$ & $(\operatorname{Pr} 10.4+\mathrm{Ac} 12.2) \mathrm{mmol} \mathrm{L}^{-1}$ \\
\hline & 14 & $2 \operatorname{Pr} 1 \mathrm{AC}$ & $(\operatorname{Pr} 52.0+\mathrm{Ac} 12.2) \mathrm{mmol} \mathrm{L}^{-1}$ \\
\hline & 15 & $3 \operatorname{Pr} 1 \mathrm{AC}$ & $(\operatorname{Pr} 104.1+\mathrm{Ac} 12.2) \mathrm{mmol} \mathrm{L}^{-1}$ \\
\hline \multirow{11}{*}{$\begin{array}{l}\text { Combined inorganic/inorganic or combined } \\
\text { inorganic/organic }\end{array}$} & 16 & 1Zn1Cu & Zn $1.0 \mathrm{mmol} \mathrm{L}{ }^{-1}+$ Cu $1.9 \mu \mathrm{mol} \mathrm{L}^{-1}$ \\
\hline & 17 & $1 \mathrm{Zn} 2 \mathrm{Cu}$ & Zn $1.0 \mathrm{mmol} \mathrm{L}^{-1}+\mathrm{Cu} 4.4 \mu \mathrm{mol} \mathrm{L}{ }^{-1}$ \\
\hline & 18 & $1 \mathrm{Zn} 3 \mathrm{Cu}$ & Zn $1.0 \mathrm{mmol} \mathrm{L}{ }^{-1}+$ Cu $6.3 \mu \mathrm{mol} \mathrm{L}-1$ \\
\hline & 19 & 1 Cu2Ac & $\mathrm{Cu} 4.4 \mu \mathrm{mol} \mathrm{L}{ }^{-1}+\mathrm{Ac} 60.9 \mathrm{mmol} \mathrm{L}^{-1}$ \\
\hline & 20 & $2 \mathrm{Cu} 2 \mathrm{Ac}$ & $\mathrm{Cu} 4.4 \mu \mathrm{mol} \mathrm{L}-1+\mathrm{Ac} 60.9 \mathrm{mmol} \mathrm{L}^{-1}$ \\
\hline & 21 & $3 C U 2 A C$ & Cu $6.3 \mu \mathrm{mol} \mathrm{L}{ }^{-1}+$ Ac $60.9 \mathrm{mmol} \mathrm{L}^{-1}$ \\
\hline & 22 & 1CU3AC & Cu $1.9 \mu \mathrm{mol} \mathrm{L}{ }^{-1}+A c 121.9 \mathrm{mmol} \mathrm{L}^{-1}$ \\
\hline & 23 & $2 \mathrm{Cu} 3 \mathrm{Ac}$ & $\mathrm{Cu} 4.4 \mu \mathrm{mol} \mathrm{L}-1+\mathrm{Ac} 121.9 \mathrm{mmol} \mathrm{L}^{-1}$ \\
\hline & 24 & 3 Cu3Ac & Cu $6.3 \mu \mathrm{mol} \mathrm{L}{ }^{-1}+$ Ac $121.9 \mathrm{mmol} \mathrm{L}^{-1}$ \\
\hline & 25 & $1 Z n 2 A c$ & $\left(\right.$ Zn $1.0+$ Ac 60.9) $\mathrm{mmol} \mathrm{L}^{-1}$ \\
\hline & 26 & $1 \mathrm{Zn} 3 \mathrm{Ac}$ & $(\mathrm{Zn} 1.0+\mathrm{Ac} 121.9) \mathrm{mmol} \mathrm{L}^{-1}$ \\
\hline
\end{tabular}

Three different concentrations of $\mathrm{Zn}$, provided as $\mathrm{ZnSO}_{4} \cdot 7 \mathrm{H}_{2} \mathrm{O}\left(1.04,2.4\right.$ and $\left.3.5 \mathrm{mmol} \mathrm{L}^{-1}\right)$ and $\mathrm{Cu}$, provided as CuSO $\mathrm{C}_{4}\left(1.9,4.4,6.3 \mu \mathrm{mol} \mathrm{L} \mathrm{L}^{-1}\right)$ were used individually or in combination (experiments \#1-6 and \#16-18). Two concentrations of acetate ( 60.9 and $\left.121.9 \mathrm{mmol} \mathrm{L}^{-1}\right)$ were tested in addition to the recommended concentration of $12.2 \mathrm{mmol} \mathrm{L}^{-1}$ (experiments \#7-9). Propionate was tested at concentrations of 10.4, 52.0 and $104.1 \mathrm{mmol} \mathrm{L}^{-1}$ without or with acetate was also tested (\#10-15). In experiments \#19-26 a combination of $\mathrm{Zn}$ or Cu with acetate was tested

Ac acetate, Pr propionate

a Medium in 1-9 contained an acetate concentration of $12.2 \mathrm{mmol} \mathrm{L}^{-1}$ as a standard nutrient for M. maripaludis growth

without acetate were performed. Moreover, the performance of $M$. maripaludis was tested with sodium propionate at $10.4,52.0$, and $104.1 \mathrm{mmol} \mathrm{L}^{-1}$ without or with acetate, respectively. Two stock solutions, $2.8 \mathrm{~mol} \mathrm{~L}^{-1}$ for acetate and a $2.6 \mathrm{~mol} \mathrm{~L}^{-1}$ for propionate, were prepared to add appropriate concentrations of those VFAs to the medium just before the inoculation. The positive control of experiments $10-12$ contained $12.2 \mathrm{mmol} \mathrm{L}^{-1}$ of acetate and $10.4 \mathrm{mmol} \mathrm{L}^{-1}$ of propionate, while in experiments 13-15 included $12.2 \mathrm{mmol} \mathrm{L}^{-1}$ of acetate. Except for negative control, the other serum bottles were inoculated with $0.5 \mathrm{~mL}$ of fresh culture and incubated as specified above.

\section{Test with $\mathrm{Cu}$ and $\mathrm{Zn}$}

Based on the results from $\mathrm{Cu}$ and $\mathrm{Zn}$ experiments, additional tests were carried out by combining $\mathrm{Zn}$
(1.0 $\left.\mathrm{mmol} \mathrm{L} \mathrm{L}^{-1}\right)$ with three distinct concentrations of $\mathrm{Cu}\left(0.019,0.044,0.063 \mathrm{mmol} \mathrm{L}^{-1}\right.$ (Table 2, 16-18). The positive control only contained $12.2 \mathrm{mmol} \mathrm{L}^{-1}$ of acetate without adding $\mathrm{Cu}$ or $\mathrm{Zn}$.

\section{Test with $\mathrm{Cu}$ or $\mathrm{Zn}$ in combination with acetate}

Double variable experiments (Table 2, 19-26) were also performed by providing $\mathrm{Cu}\left(1.9,4.4,6.3 \mathrm{mmol} \mathrm{L}^{-1}\right)$ or $\mathrm{Zn}\left(1.0 \mathrm{mmol} \mathrm{L}^{-1}\right)$ in combination with acetate $(60.9$ and $\left.121.9 \mathrm{mmol} \mathrm{L}^{-1}\right)$. The positive control contained only 60.9 or $121.9 \mathrm{mmol} \mathrm{L}^{-1}$ of acetate, respectively, without adding $\mathrm{Cu}$ or $\mathrm{Zn}$.

\section{Quantitative analysis}

$\mathrm{OD}_{578}$, biomass concentration $\left(\times\left[\mathrm{g} \mathrm{L}^{-1}\right]\right)$, specific growth rate $\left(\mu\left[\mathrm{h}^{-1}\right]\right)$, and volumetric $\mathrm{CH}_{4}$ production 
rate (MER [mmol $\mathrm{L}^{-1} \mathrm{~h}^{-1}$ ) were calculated. Values for $x$ were obtained by multiplying the OD values by $0.34 \mathrm{~g} \mathrm{~L}^{-1}$, which is the conversion factor obtained by the cell dry weight. $\mu$ was calculated as a linear parameter as follows: $\mu=\left(\mathrm{OD}_{\mathrm{t} 2}-\mathrm{OD}_{\mathrm{t} 1}\right) /\left(t_{2}-t_{1}\right)$, where $t$ is the time of incubation in hours. MER was calculated, as follows [73]: $\mathrm{MER}=\Delta n_{\mathrm{CH}_{4}} / \Delta t V$, where $\Delta n_{\mathrm{CH}_{4}}$ is the number of moles of $\mathrm{CH}_{4}$ produced per time per volume of gas, based on the pressure reduction in the head space after a period of culture incubation, $t$ is the time, and $V$ is the cultivation volume. Furthermore, the specific $\mathrm{CH}_{4}$ productivity $\left(\mathrm{qCH}_{4},\left[\mathrm{mmol} \mathrm{g}^{-1} \mathrm{~h}^{-1}\right]\right)$, which defines the catalytic power of the biomass $[8,76]$ was considered. $\mathrm{qCH}_{4}$ is calculated by dividing MER and $x$ as follows: $\mathrm{qCH}_{4}=\mathrm{MER} / x$. The above-described parameters will be shown as maximum values in order to compare the different growing conditions.

\section{VFAs analysis}

VFAs were analysed at the end of each closed batch experiments. Concentrations of acetate and propionate were determined by HPLC analysis (Agilent 1100 Series HPLC System with G1362A refractive index detector, Agilent Technologies, USA). Separation was done with an IC Sep ICE-Coregel 87H3 column (Transgenomic, Nebraska, USA) with a mobile phase of $50 \mathrm{~mol} \mathrm{~m}^{-3}$ $\mathrm{H}_{2} \mathrm{SO}_{4}$ at a flow rate of $1.5 \times 10^{-7} \mathrm{~m}^{3} \mathrm{~s}^{-1}$. Column oven and detector temperature were $65{ }^{\circ} \mathrm{C}$ and $55{ }^{\circ} \mathrm{C}$, respectively. To remove particles from liquid suspension, the samples were prepared by Carrez precipitation and centrifugation to eliminate interfering compounds [77]. For calibration, mixed standards were prepared from pure substances at concentration levels of 10, 40, 100, 500, and $1000 \mathrm{ppm}$.

\section{Acetate transporter identification}

The investigation on acetate uptake by M. maripaludis $\mathrm{S} 2$ through specific transport mechanism, started with the search for homology with MM_0903 protein sequence from Methanosarcina mazei [65]. BLAST searches were performed using the UniProt web page [78] and the NCBI platform [79]. The obtained sequences were analysed and the search for homologous was restricted to the methanococci related class to identify a candidate protein for an acetate transporter, resulting in the MMP0348 protein as the possible acetate carrier. Alignments were performed with Clustal Omega [80] and possible interactions were searched using the STRING protein-protein interaction database [72]. A protein structural model of the candidate transport protein (MMP0348) has been generated by the protein structure prediction server RaptorX [66-70].

\section{Additional files}

Additional file 1. Additional figures.

Additional file 2. Additional materials.

\section{Abbreviations}

Ac: acetate; ACS: acetyl-CoA synthase; BMP: biological methane production; $\mathrm{CH}_{4}$ : methane; $\mathrm{Co}$ : cobalt; $\mathrm{CO}_{2}$ : carbon dioxide; $\mathrm{CODH}$ : carbon monoxide dehydrogenase; $\mathrm{Cu}$ : copper; $\mathrm{H}_{2}$ : molecular hydrogen; M. maripaludis: Methanococcus maripaludis; $\mathrm{MER}_{\max }$ : maximum methane evolution rate $\left(\mathrm{mmol} \mathrm{L}^{-1} \mathrm{~h}^{-1}\right)$; $\mathrm{N}_{2}$ : molecular nitrogen; OD: optical density; $\mathrm{Pr}$ : propionate; $\mathrm{qCH}_{4}$ : specific methane production rate $\left(\mathrm{mmol} \mathrm{g}^{-1} \mathrm{~h}^{-1}\right) ; \mathrm{qCH}_{4, \max }$ : maximum specific methane production rate $\left(\mathrm{mmol} \mathrm{g} \mathrm{g}^{-1} \mathrm{~h}^{-1}\right) ; X$ : biomass $(\mathrm{g}) ; x$ : biomass concentration $\left(\mathrm{g} \mathrm{L}^{-1}\right)$; $\mathrm{Zn}$ : zinc; $\mu$ : specific growth rate $\left(\mathrm{h}^{-1}\right) ; \mu_{\max }$ : maximum specific growth rate $\left(h^{-1}\right)$.

\section{Authors' contributions}

$A A, S R$, and GB conceived the study and designed the experiments. AA performed the experiments and analysed the data. AA, RS, DF, and GB discussed and interpreted the data. AA, SR, DF, and GB wrote the manuscript. All authors read and approved the final manuscript.

\section{Author details}

${ }^{1}$ Institute for Environmental Biotechnology, IFA Department Tulln, University of Natural Resources and Life Sciences, Vienna, Austria. ${ }^{2}$ Archaea Physiology \& Biotechnology Group, Archaea Biology and Ecogenomics Division, Department of Ecogenomics and Systems Biology, Universität Wien, Althanstraße 14, 1090 Vienna, Austria. ${ }^{3}$ Department of Applied Science and Technology (DISAT), Politecnico di Torino, Turin, Italy. ${ }^{4}$ Center for Sustainable Future Technologies, Istituto Italiano di Tecnologia, Turin, Italy.

\section{Acknowledgements}

We acknowledge Dr. Lydia Rachbauer for technical support and useful scientific suggestions. Ivana Mihajlov and Verena Huber are acknowledged for VFAs analysis. Dr. Nika Pende and Dr. Angela Re are gratefully acknowledged for proofreading and comments.

\section{Competing interests}

The authors declare that the research was conducted in the absence of any commercial or financial relationships that could be construed as a potential competing interests.

\section{Funding}

Greatly acknowledged is funding from the Österreichische Forschungsförderungsgesellschaft (FFG) via the 2. Ausschreibung Energieforschung from the Klimaenergiefonds in the frame of the BioHyMe project (Grant 853615), the FFG funding for the NitroFix project (Grant 859293) from 5. Ausschreibung Research Studio Austria, the FFG funding for the project Bioraffinerie (Grant 854156), and the funding from the European Union's Horizon 2020 research and innovation program under Grant agreement number 679050 (Project: CELBICON).

\section{Publisher's Note}

Springer Nature remains neutral with regard to jurisdictional claims in published maps and institutional affiliations.

Received: 12 July 2018 Accepted: 25 October 2018

Published online: 02 November 2018

\section{References}

1. Holmes DE, Smith JA. Biologically produced methane as a renewable energy source. Adv Appl Microbiol. 2016;97:1-61.

2. Thauer RK, Kaster A-K, Seedorf H, Buckel W, Hedderich R. Methanogenic archaea: ecologically relevant differences in energy conservation. Nat Rev Microbiol. 2008;6:579-91. 
3. Argyle JL, Tumbula DL, Leigh JA. Neomycin resistance as a selectable marker in Methanococcus maripaludis. Am Soc for Microbiol. 1996;62:4233-7.

4. Tumbula DL, Makula RA, Whitman WB. Transformation of Methanococcus maripaludis and identification of a Pst I-like restriction system. FEMS Microbiol Lett. 1994;121:309-14.

5. Sarmiento FB, Leigh JA, Whitman WB. Genetic systems for hydrogenotrophic methanogens. Methods Enzymol. 2011;494:43-73.

6. Rittmann S, Seifert A, Herwig C. Essential prerequisites for successful bioprocess development of biological $\mathrm{CH}_{4}$ production from $\mathrm{CO}_{2}$ and $\mathrm{H}_{2}$. Crit Rev Biotechnol. 2013:8551:1-12.

7. Rittmann SK-MR. A critical assessment of microbiological biogas to biomethane upgrading systems. Adv Biochem Eng Biotechnol. 2015;152:117-35.

8. Rittmann SK-MR, Seifert AH, Bernacchi S. Kinetics, multivariate statistical modelling, and physiology of $\mathrm{CO}_{2}$-based biological methane production. Appl Energy. 2018;216:751-60.

9. Goyal N, Zhou Z, Karimi IA. Metabolic processes of Methanococcus maripaludis and potential applications. Microb Cell Fact. 2016;15:107.

10. Abdel Azim A, Pruckner C, Kolar P, Taubner R-S, Fino D, Saracco G, et al. The physiology of trace elements in biological methane production. Bioresour Technol. 2017;241:775-86.

11. Mauerhofer L-M, Reischl B, Schmider T, Schupp B, Nagy K, Pappenreiter $P$, et al. Physiology and methane productivity of Methanobacterium thermaggregans. Appl Microbiol Biotechnol. 2018;102:7643-56.

12. Enzmann F, Mayer F, Rother M, Holtmann D. Methanogens: biochemical background and biotechnological applications. AMB Exp. 2018:8:1.

13. Seifert AH, Rittmann S, Herwig C. Analysis of process related factors to increase volumetric productivity and quality of biomethane with Methanothermobacter marburgensis. Appl Energy. 2014;132:155-62.

14. Lyu Z, Jain R, Smith P, Fetchko T, Yan Y, Whitman WB. Engineering the autotroph Methanococcus maripaludis for geraniol production. ACS Synth Biol. 2016;5:577-81.

15. Richards MA, Lie TJ, Zhang J, Ragsdale SW, Leigh JA, Price ND. Exploring hydrogenotrophic methanogenesis: a genome scale metabolic reconstruction of Methanococcus maripaludis. J Bacteriol. 2016;198:3379-90.

16. Luna-delRisco M, Orupõld K, Dubourguier HC. Particle-size effect of CuO and $\mathrm{ZnO}$ on biogas and methane production during anaerobic digestion. J Hazard Mater. 2011;189:603-8.

17. Paulo LM, Stams AJM, Sousa DZ. Methanogens, sulphate and heavy metals: a complex system. Rev Environ Sci Biotechnol. 2015;14:537-53.

18. Jarrell KF, Saulnier M, Ley A. Inhibition of methanogenesis in pure cultures by ammonia, fatty acids, and heavy metals, and protection against heavy metal toxicity by sewage sludge. Can J Microbiol. 1987;33:551-4.

19. Sanchez JM, Valle L, Rodriguez F, Moriñigo MA, Borrego JJ. Inhibition of methanogenesis by several heavy metals using pure cultures. Lett Appl Microbiol. 1996:23:439-44.

20. Lin C-Y. Effect of heavy metals on volatile fatty acid degradation in anaerobic digestion. Water Res. 1992;26:177-83.

21. Osuna MB, Zandvoort MH, Iza JM, Lettinga G, Lens PNL. Effects of trace element addition on volatile fatty acid conversions in anaerobic granular sludge reactors. Environ Technol. 2003;24:573-87.

22. Mudhoo A, Kumar S. Effects of heavy metals as stress factors on anaerobic digestion processes and biogas production from biomass. Int J Environ Sci Technol. 2013;10:1383-98.

23. Jiang $Y$, Zhang $Y$, Banks $C$, Heaven S, Longhurst P. Investigation of the impact of trace elements on anaerobic volatile fatty acid degradation using a fractional factorial experimental design. Water Res. 2017;125:458-65.

24. Herrero A, Gomez R, Snedecor B, Tolman C, Roberts M. Growth inhibition of Clostridium thermocellum by carboxylic acids: a mechanism based on uncoupling by weak acids. Appl Microbiol Biotechnol. 1985;22:53-62.

25. Wang Y, Zhang Y, Wang J, Meng L. Effects of volatile fatty acid concentrations on methane yield and methanogenic bacteria. Biomass Bioenerg. 2009;33:848-53.

26. Tabatabaei M, Sulaiman A, Nikbakht AM, Yusof N, Najafpour G. Influential parameters on biomethane generation in anaerobic wastewater treatment plants. In: Manzanera M (ed) Alternative fuel. IntechOpen. https:// doi.org/10.5772/24681. https://www.intechopen.com/books/alternativ e-fuel/influential-parameters-on-biomethane-generation-in-anaerobicwastewater-treatment-plants.
27. Franke-Whittle $I H$, Walter $A$, Ebner $C$, Insam $H$. Investigation into the effect of high concentrations of volatile fatty acids in anaerobic digestion on methanogenic communities. Waste Manag. 2014;34:2080-9.

28. Takai K, Inoue A, Horikoshi K. Methanothermococcus okinawensis sp. nov., a thermophilic, methane-producing archaeon isolated from a Western Pacific deep-sea hydrothermal vent system. Int J Syst Evol Microbiol. 2002;52:1089-95.

29. Fuchs G, Stupperich E, Thauer RK. Acetate assimilation and the synthesis of alanine, aspartate and glutamate in Methanobacterium thermoautotrophicum. Arch Microbiol. 1978;117:61-6.

30. Mayer F, Küper U, Meyer C, Daxer S, Müller V, Rachel R, et al. AMPforming acetyl coenzyme A synthetase in the outermost membrane of the hyperthermophilic crenarchaeon Ignicoccus hospitalis. J Bacteriol. 2012;194:1572-81.

31. Starai VJ, Escalante-Semerena JC. Review acetyl-coenzyme A synthetase (AMP forming). C Cell Mol Life Sci. 2004;61:2020-30.

32. Shieh J, Whitman WB. Pathway of acetate assimilation in autotrophic and heterotrophic methanococci. 1987;169:5327-9.

33. Goyal N, Widiastuti H, Karimi IA, Zhou Z. A genome-scale metabolic model of Methanococcus maripaludis $\mathrm{S} 2$ for $\mathrm{CO}_{2}$ capture and conversion to methane. Mol BioSyst. 2014;10:1043-54.

34. Zhitnitsky D, Rose J, Lewinson O. The highly synergistic, broad spectrum, antibacterial activity of organic acids and transition metals. Sci Rep. 2017;7:1-13.

35. Hamann N, Mander GJ, Shokes JE, Scott RA, Bennati M, Hedderich R. A cysteine-rich CCG domain contains a novel [4Fe-4S] cluster binding motif as deduced from studies with subunit $B$ of heterodisulfide reductase from Methanothermobacter marburgensis. Biochemistry. 2007:46:12875-85.

36. Gencic S, LeClerc GM, Gorlatova N, Peariso K, Penner-Hahn JE, Grahame DA. Zinc-thiolate intermediate in catalysis of methyl group transfer in Methanosarcina barkeri. Biochemistry. 2001;40:13068-78.

37. Sauer K, Thauer RK. Methyl-coenzyme M formation in methanogenic archaea. Involvement of zinc in coenzyme M activation. Eur J Biochem. 2000;267:2498-504.

38. Krüer M, Haumann M, Meyer-Klaucke W, Thauer RK, Dau H. The role of zinc in the methylation of the coenzyme $M$ thiol group in methanol:coenzyme M methyltransferase from Methanosarcina barkeri. Eur J Biochem. 2002;269:2117-23.

39. Kaster A-K, Moll J, Parey K, Thauer RK. Coupling of ferredoxin and heterodisulfide reduction via electron bifurcation in hydrogenotrophic methanogenic archaea. Proc Natl Acad Sci. 2011;108:2981-6.

40. Seravalli J, Xiao Y, Gu W, Cramer SP, Antholine WE, Krymov V, et al. Evidence that NiNi acetyl-CoA synthase is active and that the CuNi enzyme is not. Biochemistry. 2004;43:3944-55.

41. Tan X, Bramlett MR, Lindahl PA. Effect of Zn on acetyl coenzyme A synthase: evidence for a conformational change in the a subunit during catalysis. J Am Chem Soc. 2004;126:5954-5.

42. Bender G, Pierce E, Hill JA, Darty JE, Ragsdale SW. Metal centers in the anaerobic microbial metabolism of $\mathrm{CO}$ and $\mathrm{CO}_{2}$. Metallomics. 2011;3:797-815.

43. Haque Md, Subramanian V. Copper, Lead, and Zinc pollution of soil environment. Critic Rev Environ Sci Technol. 1982;1:1-32.

44. Tchounwou PB, Yedjou CG, Patlolla AK, Sutton DJ. Heavy metals toxicity and the environment. In: Luch A, editor. Molecular, clinical and environmental toxicology, vol. 101. Berlin: Experientia Supplementum; 2012. p. 133-64.

45. Hamelink J, Landrum PF, Bergman H, Benson WH. Bioavailability: physical, chemical, and biological interactions. In: Hamelink J, Landrum PF, Bergman H, Benson WH, eds. Lewis Publishers; 1994.

46. Seravalli J, Gu W, Tam A, Strauss E, Begley TP, Cramer SP, et al. Functional copper at the acetyl-CoA synthase active site. Proc Natl Acad Sci. 2003;100(7):3689-94.

47. Mori K, Hatsu M, Kimura R, Takamizawa K. Effect of heavy metals on the growth of a methanogen in pure culture and coculture with a sulfatereducing bacterium. J Biosci Bioeng. 2000;90:260-5.

48. Zayed G, Winter J. Inhibition of methane production from whey by heavy metals - protective effect of sulfide. Appl Microbiol Biotechnol. 2000;53:726-31.

49. Villa-Gomez DK, Papirio S, van Hullebusch ED, Farges F, Nikitenko S,

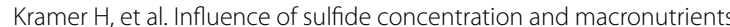


on the characteristics of metal precipitates relevant to metal recovery in bioreactors. Bioresour Technol. 2012;110:26-34.

50. Ricke S. Perspectives on the use of organic acids and short chain fatty acids as antimicrobials. Poult Sci. 2003;82:632-9.

51. Shieh JS, Whitman WB. Pathway of acetate assimilation in autotrophic and heterotrophic methanococci. J Bacteriol. 1987;169:5327-9.

52. Musfeldt M, Schönheit P. Novel type of ADP-forming acetyl coenzyme A synthetase in hyperthermophilic archaea: heterologous expression and characterization of isoenzymes from the sulfate reducer Archaeoglobus fulgidus and the methanogen Methanococcus jannaschii. J Bacteriol. 2002:184:636-44.

53. Hendrickson EL, Kaul R, Zhou Y, Bovee D, Chapman P, Chung J, et al. Complete genome sequence of the genetically tractable hydrogenotrophic methanogen Methanococcus maripaludis. J Bacteriol. 2004;186:6956-69.

54. Bräsen C, Schönheit P. Mechanisms of acetate formation and acetate activation in halophilic archaea. Arch Microbiol. 2001;175:360-8.

55. Glasemacher J, Bock AK, Schmid R, Schønheit P. Purification and properties of acetyl-CoA synthetase (ADP-forming), an archaeal enzyme of acetate formation and ATP synthesis, from the hyperthermophile Pyrococcus furiosus. Eur J Biochem. 1997:244:561-7.

56. Baronofsky JJ, Schreurs WJ, Kashket ER. Uncoupling by acetic acid limits growth of and acetogenesis by Clostridium thermoaceticum. Appl Environ Microbiol. 1984;48:1134-9.

57. Gutknecht J. Proton conductance through phospholipid bilayers: water wires or weak acids? J Bioenergy Biomembr. 1987;19:427-42.

58. Fukuzaki S, Nishio N, Shobayashi M, Nagai S. Inhibition of the fermentation of propionate to methane by hydrogen, acetate, and propionate. Appl Environ Microbiol. 1990;56:719-23.

59. Mani-López E, García HS, López-Malo A. Organic acids as antimicrobials to control Salmonella in meat and poultry products. Food Res Int. 2012:45:713-21.

60. Bramlett MR, Tan X, Lindahl PA. Inactivation of acetyl-CoA synthase/ carbon monoxide dehydrogenase by copper. J Am Chem Soc. 2003;125:9316-7.

61. Lindahl PA. The Ni-containing carbon monoxide dehydrogenase family: light at the end of the tunnel? Biochemistry. 2002;41:2097-105.

62. Tan X, Surovtsev IV, Lindahl PA. Kinetics of CO insertion and acetyl group transfer steps, and a model of the acetyl-CoA synthase catalytic mechanism. J Am Chem Soc. 2006;128:12331-8.

63. Paiva S, Devaux F, Barbosa S, Jacq C, Casal M. Ady2p is essential for the acetate permease activity in the yeast Saccharomyces cerevisiae. Yeast. 2004;21:201-10.
64. Sá-Pessoa J, Paiva S, Ribas D, Silva IJ, Viegas SC, Arraiano CM, et al. SATP (YaaH), a succinate-acetate transporter protein in Escherichia coli. Biochem J. 2013:454:585-95.

65. Welte C, Deppenmeier U. Bioenergetics and anaerobic respiratory chains of aceticlastic methanogens. Biochim Biophys Acta. 2014;1837:1130-47.

66. Källberg M, Wang H, Wang S, Peng J, Wang Z, Lu H, et al. Template-based protein structure modeling using the RaptorX web server. Nat Protocols. 2012;7:1511-22.

67. Peng J, Xu J. Raptorx: exploiting structure information for protein alignment by statistical inference. Proteins Struct Funct Bioinf. 2011;79:161-71.

68. Peng J, Xu J. A multiple-template approach to protein threading. Proteins Struct Funct Bioinf. 2011;79:1930-9.

69. Ma J, Frear C, Wang Z, Yu L, Zhao Q, Li X, et al. A simple methodology for rate-limiting step determination for anaerobic digestion of complex substrates and effect of microbial community ratio. Bioresour Technol. 2013;134:391-5.

70. Ma J, Peng J, Wang S, Xu J. A conditional neural fields model for protein threading. Bioinformatics. 2012;28:i59-66.

71. Qiu B, Xia B, Zhou Q, Lu Y, He M, Hasegawa K, et al. Succinate-acetate permease from Citrobacter koseri is an anion channel that unidirectionally translocates acetate. Cell Res. 2018;28:654-5.

72. STRING: functional protein association networks. https://string-db.org/.

73. Taubner R-S, Rittmann SK-MR. Method for indirect quantification of $\mathrm{CH}_{4}$ production via $\mathrm{H}_{2} \mathrm{O}$ production using hydrogenotrophic methanogens. Front Microbiol. 2016;7:532.

74. Whitman WB, Shieh J, Sohn S, Caras DS, Premachandran U. Isolation and characterization of 22 mesophilic methanococci. Syst Appl Microbiol. 1986;7:235-40

75. Kessler PS, Blank C, Leigh JA. The nif gene operon of the methanogenic archaeon Methanococcus maripaludis. J Bacteriol. 1998;180:1504-11.

76. Rittmann S, Seifert A, Herwig C. Quantitative analysis of media dilution rate effects on Methanothermobacter marburgensis grown in continuous culture on $\mathrm{H}_{2}$ and $\mathrm{CO}_{2}$. Biomass Bioenergy. 2012;36:293-301.

77. Rachbauer L, Voitl G, Bochmann G, Fuchs W. Biological biogas upgrading capacity of a hydrogenotrophic community in a trickle-bed reactor. Appl Energy. 2016;180:483-90.

78. UniProtKB. https://www.uniprot.org/blast/.

79. BLAST: Basic Local Alignment Search Tool. https://blast.ncbi.nlm.nih.gov/ Blast.cgi.

80. UniProtKB Align. https://www.uniprot.org/align/.
Ready to submit your research? Choose BMC and benefit from:

- fast, convenient online submission

- thorough peer review by experienced researchers in your field

- rapid publication on acceptance

- support for research data, including large and complex data types

- gold Open Access which fosters wider collaboration and increased citations

- maximum visibility for your research: over $100 \mathrm{M}$ website views per year

At BMC, research is always in progress.

Learn more biomedcentral.com/submissions 